\title{
A Presynaptic Group III mGluR Recruits G $\beta \gamma /$ SNARE Interactions to Inhibit Synaptic Transmission by Cone Photoreceptors in the Vertebrate Retina
}

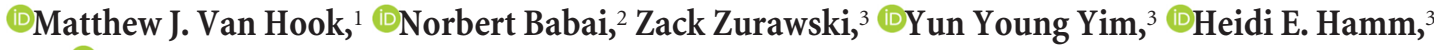 \\ and ${ }^{\circ}$ Wallace B. Thoreson ${ }^{1,4}$ \\ ${ }^{1}$ Truhlsen Eye Institute, Department of Ophthalmology and Visual Sciences, University of Nebraska Medical Center, Omaha, Nebraska 68198, ${ }^{2}$ Department \\ of Biology, Animal Physiology, University of Erlangen-Nuremberg, 91058 Erlangen, Germany, ${ }^{3}$ Department of Pharmacology, Vanderbilt University \\ Medical School, Nashville, Tennessee 37232, and ${ }^{4}$ Department of Pharmacology and Experimental Neuroscience, University of Nebraska Medical Center, \\ Omaha, Nebraska 68198
}

G-protein $\beta \gamma$ subunits $(\mathrm{G} \beta \gamma)$ interact with presynaptic proteins and regulate neurotransmitter release downstream of $\mathrm{Ca}^{2+}$ influx. To accomplish their roles in sensory signaling, photoreceptor synapses use specialized presynaptic proteins that support neurotransmission at active zone structures known as ribbons. While several G-protein coupled receptors (GPCRs) influence synaptic transmission at ribbon synapses of cones and other retinal neurons, it is unknown whether $\mathrm{G} \beta \gamma$ contributes to these effects. We tested whether activation of one particular GPCR, a metabotropic glutamate receptor (mGluR), can reduce cone synaptic transmission via G $\beta \gamma$ in tiger salamander retinas. In recordings from horizontal cells, we found that an mGluR agonist (L-AP4) reduced cone-driven light responses and $\mathrm{mEPSC}$ frequency. In paired recordings of cones and horizontal cells, L-AP4 slightly reduced cone $\mathrm{I}_{\mathrm{Ca}}(\sim 10 \%)$ and caused a larger reduction in cone-driven EPSCs $(\sim 30 \%)$. Proximity ligation assay revealed direct interactions between SNAP- 25 and G $\beta \gamma$ subunits in retinal synaptic layers. Pretreatment with the SNAP-25 cleaving protease BoNT/A inhibited L-AP4 effects on synaptic transmission, as did introduction of a peptide derived from the SNAP- $25 \mathrm{C}$ terminus. Introducing $\mathrm{G} \beta \gamma$ subunits directly into cones reduced $\mathrm{EPSC}$ amplitude. This effect was inhibited by BoNT/A, supporting a role for $\mathrm{G} \beta \gamma / \mathrm{SNAP}-25$ interactions. However, the mGluR-dependent reduction in $\mathrm{I}_{\mathrm{Ca}}$ was not mimicked by $\mathrm{G} \beta \gamma$, indicating that this effect was independent of $\mathrm{G} \beta \gamma$. The finding that synaptic transmission at cone ribbon synapses is regulated by G $\beta \gamma / \mathrm{SNAP}-25$ interactions indicates that these mechanisms are shared by conventional and ribbon-type synapses. G $\beta \gamma$ liberated from other photoreceptor GPCRs is also likely to regulate synaptic transmission.

Key words: G-protein coupled receptor; mGluR; retina; ribbon; SNARE complex; synapse

\section{Significance Statement}

Dynamic regulation of synaptic transmission by presynaptic G-protein coupled receptors shapes information flow through neural circuits. At the first synapse in the visual system, presynaptic metabotropic glutamate receptors (mGluRs) regulate cone photoreceptor synaptic transmission, although the mechanisms and functional impact of this are unclear. We show that mGluRs regulate light response encoding across the cone synapse, accomplished in part by triggering G-protein $\beta \gamma$ subunits $(\mathrm{G} \beta \gamma)$ interactions with SNAP-25, a core component of the synaptic vesicle fusion machinery. In addition to revealing a role in visual processing, this provides the first demonstration that $\mathrm{G} \beta \gamma / \mathrm{SNAP}-25$ interactions regulate synaptic function at a ribbon-type synapse, contributing to an emerging picture of the ubiquity of G $\beta \gamma /$ SNARE interactions in regulating synaptic transmission throughout the nervous system.

\section{Introduction}

Early-stage visual processing in the vertebrate retina relies on the unique synaptic signaling capabilities of rod and cone photoreceptors. Changes in membrane voltage due to photon absorption

Received Sept. 20, 2016; revised March 27, 2017; accepted March 28, 2017

Author contributions: M.J.V.H., N.B., Z.Z.,Y.Y.Y., H.E.H., and W.B.T. designed research;M.J.V.H., N.B., and W.B.T.

performed research; Z.Z., Y.Y.Y., and H.E.H. contributed unpublished reagents/analytic tools; M.J.V.H., N.B., and

W.B.T. analyzed data; M.J.V.H. and W.B.T. wrote the paper. in photoreceptor outer segments regulate tonic glutamate release at the synaptic terminal. Photoreceptor synapses differ from their conventional counterparts in a number of ways. For instance, exocytosis depends on large planar protein structures known as

This work was supported by National Institutes of Health Grants EY10542 to W.B.T., F32EY023864 to M.J.V.H. EY010291 to H.E.H., MH101679 to H.E.H., and DK109204 to H.E.H., and Research to Prevent Blindness Senior Scientific Investigator Award to W.B.T.

The authors declare no competing financial interests. 
ribbons that tether vesicles near the presynaptic membrane and ready them for exocytosis (Heidelberger et al., 2005). Rather than relying on the $\mathrm{N}$ - and $\mathrm{P}$-type channels common at conventional synapses, photoreceptors use minimally inactivating L-type $\mathrm{Ca}^{2+}$ channels to provide a tonic $\mathrm{Ca}^{2+}$ signal that reflects photoreceptor membrane voltage (Corey et al., 1984; Morgans, 2001). Additionally, they rely on Syntaxin3 and Complexin3/4 rather than Syntaxin 1 and Complexin $1 / 2$ isoforms used at many other synapses (Morgans et al., 1996; Reim et al., 2005). Photoreceptors also use a $\mathrm{Ca}^{2+}$ sensor of unknown molecular identity with unusually high $\mathrm{Ca}^{2+}$ affinity and low cooperativity that differs from synaptotagmin $1 / 2$ found at conventional synapses (Rieke and Schwartz, 1996; Thoreson et al., 2004; Duncan et al., 2010).

Photoreceptor synaptic transmission is under dynamic regulation by a variety of G-protein-coupled receptors (GPCRs) sensitive to ligands, including dopamine, adenosine, endocannabinoids, glutamate, and somatostatin (Straiker et al., 1999; Akopian et al., 2000; Stella and Thoreson, 2000; Hirasawa et al., 2002; Stella et al., 2002, 2007, 2009; Fan and Yazulla, 2004; Hosoi et al., 2005; Struik et al., 2006). These can influence synaptic output by enhancing or reducing $\mathrm{Ca}^{2+}$ influx (Stella and Thoreson, 2000; Stella et al., 2002, 2007, 2009), as well as by actions on other presynaptic currents (Akopian and Witkovsky, 1996; Akopian et al., 2000; Straiker and Sullivan, 2003; Fan and Yazulla, 2004). GPCRs signal to downstream effectors via heterotrimeric G-proteins comprised of an $\alpha$ subunit $(\mathrm{G} \alpha)$ and beta-gamma subunit complex $(\mathrm{G} \beta \gamma)$. At synapses, $\mathrm{G} \beta \gamma$ can interact directly with $\mathrm{P} / \mathrm{Q}$ and $\mathrm{N}$-type $\mathrm{Ca}^{2+}$ channels and inwardly rectifying $\mathrm{K}^{+}$channels to modulate presynaptic $\mathrm{Ca}^{2+}$ signals (Logothetis et al., 1987; Tedford and Zamponi, 2006; Currie, 2010). In addition, $G \beta \gamma$ can also inhibit synaptic vesicle exocytosis downstream of $\mathrm{Ca}^{2+}$ influx by interacting directly with SNARE proteins, most notably SNAP-25, where it competes with $\mathrm{Ca}^{2+}$-dependent synaptotagmin interactions (Blackmer et al., 2001, 2005; Gerachshenko et al., 2005; Yoon et al., 2007; Betke et al., 2012; Wells et al., 2012).

A role for $\mathrm{G} \beta \gamma / \mathrm{SNARE}$ interactions in regulating synaptic transmission is well established in several systems (Blackmer et al., 2005; Gerachshenko et al., 2005; Delaney et al., 2007; Zhang et al., 2011; Hamid et al., 2014), yet it is unclear whether this occurs at retinal ribbon synapses with their specialized complement of synaptic proteins and distinct signaling properties. In this study, we leverage a powerful set of approaches, including paired whole-cell recordings, whole-cell capacitance recordings, $\mathrm{MEPSC}$ and quantal glutamate transporter current analyses, and proximity ligation assay (PLA) to test whether activation of Group III metabotropic glutamate receptors (mGluRs) recruits $\mathrm{G} \beta \gamma / \mathrm{SNARE}$ interactions to regulate glutamate release at cone ribbon synapses. This was motivated, in part, by work showing that $\mathrm{mGluR}$ activation caused an $\sim 15 \%$ reduction in $\mathrm{Ca}^{2+}$ influx yet a $30 \%-50 \%$ decrease in synaptic transmission (Hosoi et al., 2005). Because photoreceptor exocytosis depends linearly on $\mathrm{Ca}^{2+}$ influx (Thoreson et al., 2004; Duncan et al., 2010), a 15\% in $\mathrm{I}_{\mathrm{Ca}}$ reduction should also cause a $15 \%$ reduction in exocytosis. The mismatch hinted at processes regulating exocytosis downstream of $\mathrm{Ca}^{2+}$ influx. Here, we show that mGluRs modulate cone synaptic transmission by two distinct mechanisms: (1) direct interaction of $\mathrm{G} \beta \gamma$ with SNAP-25 and (2) reduction in $\mathrm{Ca}^{2+}$ influx independently of $\mathrm{G} \beta \gamma$. This reveals an important mechanism for modulating output at photoreceptor ribbon synapses, and shows that G $\beta \gamma / \mathrm{SNARE}$

Correspondence should be addressed to Dr. Matthew J. Van Hook, Department of Ophthalmology and Visual Sciences, University of Nebraska Medical Center, Durham Research Center 1, Room 4009, 985840 Nebraska Medical Center, Omaha, NE68198-5840. E-mail: matt.vanhook@unmc.edu.

DOI:10.1523/JNEUROSCI.2948-16.2017

Copyright $\odot 2017$ the authors $\quad 0270-6474 / 17 / 374619-17 \$ 15.00 / 0$ interactions are a widespread mechanism capable of regulating transmission at both ribbon-style and conventional synapses. Liberation of G $\beta \gamma$ by activation of other GPCRs, perhaps even including opsins, are also likely to regulate release from photoreceptors in a similar manner.

\section{Materials and Methods}

Animals. We performed experiments using retinas of aquatic tiger salamanders (Ambystoma tigrinum; Charles Sullivan) of either sex. Care and handling protocols were reviewed and approved by the Institutional Animal Care and Use Committee at the University of Nebraska Medical Center. Salamanders were housed on a $12 \mathrm{~h} \mathrm{light/dark}$ cycle at $4^{\circ} \mathrm{C}-8^{\circ} \mathrm{C}$.

Retinal slices. A video of our retinal slice and electrophysiology protocols has been published previously (Van Hook and Thoreson, 2013). At 1-2 $\mathrm{h}$ after the beginning of the animals' dark cycle, salamanders were immersed in MS222 (0.25 g/L) for $15 \mathrm{~min}$. Under room light, they were then decapitated and quickly pithed and the heads were hemisected. Under fiber optic illumination ( $1000 \mathrm{lux})$, an eye was enucleated and nested on a saline-soaked wad of cotton on a linoleum block. The anterior portion of the eye was removed, and the resulting eyecup was cut into 2-4 pieces, which were placed vitreal side down on a piece of nitrocellulose membrane $(5 \times 10 \mathrm{~mm}$; type AAWP, $0.8 \mu \mathrm{m}$ pores; EMD Millipore). The filter paper was submerged in cold amphibian saline, and the sclera was peeled away, leaving the retina adhering to the membrane. The retina was cut into $125 \mu \mathrm{m}$ slices using a razor blade tissue slicer (Stoelting). The resulting slices were rotated 90 degrees to view the retinal layers and anchored in the recording chamber by embedding the ends of the nitrocellulose membrane in beads of vacuum grease.

Patch-clamp electrophysiology. For whole-cell patch-clamp recordings, the recording chamber with slices was transferred to the stage of an upright fixed-stage microscope (Nikon E600FN or Olympus BX51WI). The slices were continuously superfused with an oxygenated amphibian saline solution containing the following (in $\mathrm{mm}$ ): $116 \mathrm{NaCl}, 2.5 \mathrm{KCl}, 1.8$ $\mathrm{CaCl}_{2}, 0.5 \mathrm{MgCl}_{2} 5$ glucose, and 10 HEPES. For experiments testing the $\mathrm{Ca}^{2+}$ sensitivity of release following BoNT/A treatment, we prepared an amphibian saline solution in which $\left[\mathrm{CaCl}_{2}\right]$ was reduced to $1.0 \mathrm{~mm}$ and $\left[\mathrm{MgCl}_{2}\right]$ was increased to $1.3 \mathrm{~mm}$ to maintain overall divalent concentration. The $\mathrm{pH}$ of amphibian saline solutions was adjusted to 7.8 with $\mathrm{NaOH}$ and the osmolality was $240-245 \mathrm{mOsm}$, as measured with a vapor pressure osmometer (Wescor). All reagents were obtained from SigmaAldrich unless specified otherwise.

Patch pipettes were pulled from borosilicate glass (1.2 mm OD, 0.9 $\mathrm{mm}$ ID, with an internal filament; World Precision Instruments) using PC-10 or PP-830 vertical pullers (Narishige) or a Sutter P-1000 Flaming/ Brown style puller. Patch pipettes had tip diameters of $\sim 1$ micron and resistances of 15-20 $\mathrm{m} \Omega$. Synaptic transmission was monitored using paired whole-cell recordings from cones and horizontal cells (HCs).

The standard pipette solution for cones contained the following (in $\mathrm{mM}$ ): 50 Cs-gluconate, 40 Cs-glutamate, 10 TEA-Cl, $3.5 \mathrm{NaCl}, 1 \mathrm{CaCl}_{2}, 1 \mathrm{MgCl}_{2}$, 10 ATP-Mg, 0.5 GTP-Na, 10 HEPES, and 5 EGTA. The addition of glutamate to the cone pipette solution enhances synaptic currents and helps to minimize rundown in whole-cell recordings by supplying glutamate for synaptic vesicles (Bartoletti and Thoreson, 2011). The pipette solution for HC pipettes was identical, except that the $40 \mathrm{~mm}$ Cs-glutamate was replaced with an additional $40 \mathrm{~mm}$ Cs-gluconate. For perforated patch recordings, we included a combination of gramicidin $(5 \mu \mathrm{g} / \mathrm{ml})$ and amphotericin-B (200 $\mu \mathrm{M})$ in the pipette solution. Gramicidin was diluted from a $5 \mathrm{mg} / \mathrm{ml}$ stock in $95 \%$ ethanol and amphotericin-B from a $200 \mathrm{~mm}$ stock in DMSO. Pipette solutions with perforating agents were protected from light and prepared fresh every $3 \mathrm{~h}$. Reported voltages were corrected for the measured liquid junction potential of $9 \mathrm{mV}$.

Synaptic transmission was monitored using paired whole-cell recordings from cones and HCs. The identity of HCs was confirmed by their morphology, position in the slice, and electrophysiological characteristics (Van Hook and Thoreson, 2013). HCs were voltage-clamped at -69 $\mathrm{mV}$, and cones were voltage-clamped at $-79 \mathrm{mV}$. Synaptic vesicle exocytosis from cones was evoked by a $100 \mathrm{~ms}$ step depolarization to -19 $\mathrm{mV}$, which is sufficient to deplete the readily releasable pool of vesicles 
(Bartoletti et al., 2010). Leak and capacitative currents were subtracted using a $\mathrm{P} / 8$ leak subtraction protocol. We measured glutamate transporter currents in cones (Picaud et al., 1995a, b), both spontaneous quantal currents and those evoked by depolarization, using the following pipette solution (in $\mathrm{mM}$ ): 90 potassium thiocyanate, 10 TEA-Cl, 3.5 $\mathrm{NaCl}, 1 \mathrm{MgCl}_{2}$, 10 HEPES, 0.05 EGTA, 10 ATP-Mg, 0.5 GTP-Na. Thiocyanate $\left(\mathrm{SCN}^{-}\right)$is a more permeant anion through glutamate transporters (Szmajda and Devries, 2011; Grabner et al., 2015) and thereby boosts the amplitude of individual events.

$\mathrm{HC}$ responses to the $2 \mathrm{~Hz}$ square wave light stimulus (1100 Lux) were recorded in the presence of a rod-adapting background delivered from a blue LED $\left(470 \mathrm{~nm} ; 3.3 \times 10^{12}\right.$ photons $\left./ \mathrm{cm}^{2} / \mathrm{s}\right)$. For white light stimuli, we controlled voltage across a white light LED using an isolated pulse stimulator (A-M Systems, model 2100). Light intensity was calibrated by measuring power at a variety of voltages and converted to Lux by assuming a luminous efficacy of 100 Lumens/W.

Whole-cell membrane capacitance $\left(\mathrm{C}_{\mathrm{m}}\right)$ recordings were performed as described previously (Van Hook and Thoreson, 2012) using the "track-in" mode of an Optopatch patch-clamp amplifier (Cairn Research). $\mathrm{CsCl}$ (3 mM) and DL-threo-b-benzyloxyaspartic acid (TBOA, 100 $\mu \mathrm{M}$, Tocris Bioscience) were added to the bath solution to minimize conductance changes due to $\mathrm{I}_{\mathrm{h}}$ and glutamate transporters, respectively. Amplifier output of membrane current, $\mathrm{C}_{\mathrm{m}}$, and access resistance were digitized with a Digidata 1322A AD/DA board and acquired with pClamp 10.4 software (Molecular Devices; RRID:SCR_011323). The shafts of patch pipettes were coated with dental wax to reduce stray capacitance, and whole-cell recordings were established by positioning the pipette tip on the ellipsoid. The holding potential was varied sinusoidally at $\sim 500 \mathrm{~Hz}, 30 \mathrm{mV}$ peak-to-peak around a holding potential of -79 $\mathrm{mV}$. Synaptic vesicle exocytosis was evoked with a depolarizing step $(-79$ to $-19 \mathrm{mV}, 25 \mathrm{~ms}$ ), and output from the phase-lock amplifier was blanked for $3 \mathrm{~ms}$ after the step to avoid the influence of gating charges and to allow time for the phase angle feedback circuitry to settle. $C_{m}$ measurements were made $\sim 30 \mathrm{~ms}$ following the end of the step. We excluded cells with sizeable poststimulus changes in series resistance.

ct-SNAP-25 peptide synthesis. We synthesized SNAP-25 193-206 peptides using the ResPep SL peptide synthesizer (Intavis AG) method published previously (Wells et al., 2012). Samples were further purified on a Gilson preparative reversed-phase HPLC system with a reverse-phase C18 column (Luna, $30 \times 50 \mathrm{~mm}$; Phenomenex) at $50 \mathrm{ml} / \mathrm{min}$ with a $5 \%-95 \%$ acetonitrile in water gradient with $0.1 \%$ TFA over $7 \mathrm{~min}$. Samples were then subjected to liquid chromatography/mass spectrometry (6120 LCMS; Agilent Technologies) for purity and mass spectrometric identification of the peptide. HPLC fractions were evaporated to retrieve the peptide of interest.

Drugs and pharmacology. G-protein $\beta_{1} \gamma_{1}$ subunits were purified from bovine retina as described previously (Mazzoni et al., 1991). G $\beta_{1} \gamma_{1}$ was diluted in the cone pipette solution $(0.3-2 \mu \mathrm{M})$ from a stock $(5.5 \mathrm{mg} / \mathrm{ml})$. As a control for $\mathrm{G} \beta_{1} \gamma_{1}$ experiments, we incubated an aliquot of the $\mathrm{G} \beta_{1} \gamma_{1}$ stock in a boiling water bath for 20-30 min before diluting it in pipette solution. In other experiments, we included ct-SNAP-25 peptide (D-E-A-N-Q-R-A-T-K-M-L-G-S-G) (Gerachshenko et al., 2005) in the cone pipette solution $(1 \mu \mathrm{M})$ from a freshly made stock $(500 \mu \mathrm{M}$ in DMSO). We used the selective Group III mGluR agonist L-AP4 (L-(+)2-amino-4-phosphonobutyric acid) to probe the involvement of mGluRs in regulating cone synaptic transmission. Because the $\mathrm{K}_{\mathrm{d}}$ of Group III mGluR's for L-AP4 is reported to vary from $\sim 1 \mu \mathrm{M}$ for mGluR4, 6, and 8 at 160-1300 $\mu \mathrm{M}$ for mGluR7 (Schoepp et al., 1999), $\mathrm{L}-\mathrm{AP} 4$ was used at a working concentration of $100 \mu \mathrm{M}$. L-AP4 was diluted in amphibian saline from a $10 \mathrm{~mm}$ stock solution made in $\mathrm{H}_{2} \mathrm{O}$ and bath-applied to the slices. For "vehicle controls," water was diluted into the amphibian saline and applied to the tissue. Botulinum neurotoxin A (BoNT/A, List Biological Laboratories) was diluted to $20 \mathrm{~nm}$ in amphibian saline from a $1 \mu \mathrm{m}$ stock. Slices were incubated in BoNT/A for 30-60 min before being washed three times with amphibian saline and used for electrophysiological recordings.

Electrophysiology analysis. Electrophysiology data were analyzed with Clampfit 10.4 (Molecular Devices; RRID:SCR_011323). Evoked EPSC amplitude was measured at the peak of the EPSC. $\mathrm{Ca}^{2+}$ influx was mea- sured as the total $\mathrm{Ca}^{2+}$ charge transfer over the $100 \mathrm{~ms}$ step $\left(\mathrm{Q}_{\mathrm{Ca}}\right) . \mathrm{I}_{\mathrm{Ca}}$ voltage dependence was measured by correcting $\mathrm{Q}_{\mathrm{Ca}}$ for driving force and fitting with a Boltzman function in GraphPad Prism 4 (RRID: SCR_002798). For measuring the $\mathrm{Ca}^{2+}$ dependence of vesicle exocytosis, we measured EPSCs evoked by steps to a series of test potentials from a holding potential of $61 \mathrm{mV}$. The average $\mathrm{Ca}^{2+}$ current was extrapolated from a fit of responses to a voltage ramp ( -99 to $51 \mathrm{mV}, 0.5 \mathrm{mV} / \mathrm{ms}$ ) by fitting with a Boltzmann function adjusted for the $\mathrm{I}_{\mathrm{Ca}}$ reversal potential $\left(\mathrm{V}_{\text {rev }}=50 \mathrm{mV}\right)$ to compensate for lingering voltage-gated $\mathrm{K}^{+}$current at depolarized potentials as follows:

$$
I\left(V_{m}\right)=\left(V_{\mathrm{rev}}-V_{m}\right) * \frac{I_{\max }}{1+e^{\frac{V_{50}-V_{m}}{\text { slope }}}}
$$

EPSC amplitude was plotted against $\mathrm{I}_{\mathrm{Ca}}$ amplitude, and the data were fit with a linear regression to test for a linear correlation of synaptic vesicle release and $\mathrm{Ca}^{2+}$ influx. $\mathrm{G} \beta_{1} \gamma_{1}$ dose dependence was assessed by fitting with a sigmoidal dose-response curve. mEPSCs and spontaneous quantal transporter currents were detected and analyzed using Mini Analysis 6.0.7 (Synaptosoft; RRID:SCR_002184). Mini Analysis uses a multiparameter sequential algorithm for detecting mEPSC waveforms rather than a simple amplitude threshold to minimize false-positive detections arising from noise and baseline current fluctuations. Mini Analysis first finds a local maximum and baseline, then, in sequence, calculates amplitude, time to peak, time to decay, and area. After automatic detection, we evaluated detected events by eye. Double peaks were analyzed using an algorithm within Mini Analysis that adjusts the baseline of the second peak by extrapolating the exponential decay of the first peak. Event frequency was calculated for each cell as an average of the instantaneous frequency calculated from interevent intervals of 100-200 individual events. Event amplitude for each cell was calculated as the mean amplitude of all the detected events for each cell. Event kinetics (rise and decay time constants) was calculated from the average of all detected events in a given cell. To quantify the kinetics of endocytosis, we measured the $t_{(50)}$, which was the time to $50 \%$ recovery of the measured response from the end of the depolarizing step. Data are presented as mean \pm SEM, and statistical significance was evaluated with two-tailed unpaired or paired Student's $t$ tests with $p<0.05$ being considered statistically significant. In some instances, the nonparametric Wilcoxon sign-rank test (paired samples) was also used, as indicated.

Immunofluorescence and PLA. For immunohistochemistry, salamander eyes were enucleated and the anterior portion, including the lens and vitreous were removed. The remaining eyecups were fixed in a $4 \%$ PFA solution in PBS for $1 \mathrm{~h}$ at room temperature. After a brief wash with PBS, they were cryoprotected in $30 \%$ sucrose overnight, and then embedded in Tissue-Tek OCT compound, frozen, and cut into $30 \mu \mathrm{m}$ sections that were mounted on Superfrost Plus microscope slides (Fisher). Sections were blocked and permeabilized with a solution of $0.5 \%$ Triton X-100 (Sigma) and 5.5\% donkey serum before being incubated with primary antibodies overnight at $4^{\circ} \mathrm{C}$. The following day, sections were washed in PBS, blocked, and incubated with AlexaFluor-488 or 568-conjugated secondary antibodies (1:200 dilution, AB_2534104, RRID:AB_2534102, RRID:AB_2535792, RRID:AB_2535788, RRID:AB_2534017). They were then washed again and coverslipped with Fluoro-Gel (Electron Microscopy Sciences). For immunocytochemistry, a whole salamander retina was isolated in $\mathrm{Ca}^{2+}$-free amphibian saline (in mM as follows: $116 \mathrm{NaCl}$, $2.5 \mathrm{KCl}, 5 \mathrm{MgCl}_{2}, 5$ glucose, $10 \mathrm{HEPES}, \mathrm{pH} 7.4$ ) before being incubated in $\mathrm{Ca}^{2+}$-free saline with $0.2 \mathrm{mg} / \mathrm{ml}$ cysteine and 30 units/ml papain (Worthington Biochemical) for $30 \mathrm{~min}$. Retinas were washed successively in $\mathrm{Ca}^{2+}$-free saline with $1 \%$ BSA (Sigma), $\mathrm{Ca}^{2+}$-free saline alone, and $\mathrm{Ca}^{2+}$-free saline containing $1 \mathrm{mg} / \mathrm{ml}$ DNase (Worthington). Retinas were then gently triturated in amphibian saline solution, and cells were allowed to settle onto concanavalin A-coated Superfrost Plus microscope slides for $60 \mathrm{~min}$ at $4^{\circ} \mathrm{C}$. Cells were then fixed with $4 \%$ PFA for $15 \mathrm{~min}$ before being washed with PBS. Antibody staining was performed as for retinal sections. SNAP-25 was probed using a mouse monoclonal antibody that is specific for SNAP-25 (EMD Millipore, MAB331, RRID: AB_94805 1:100 dilution). The immunogen was a crude human brain 


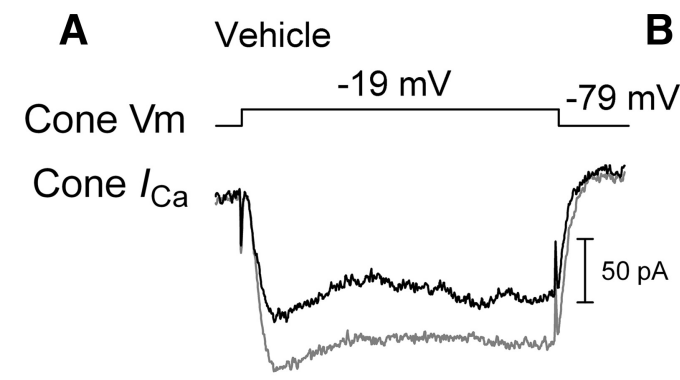

B L-AP4
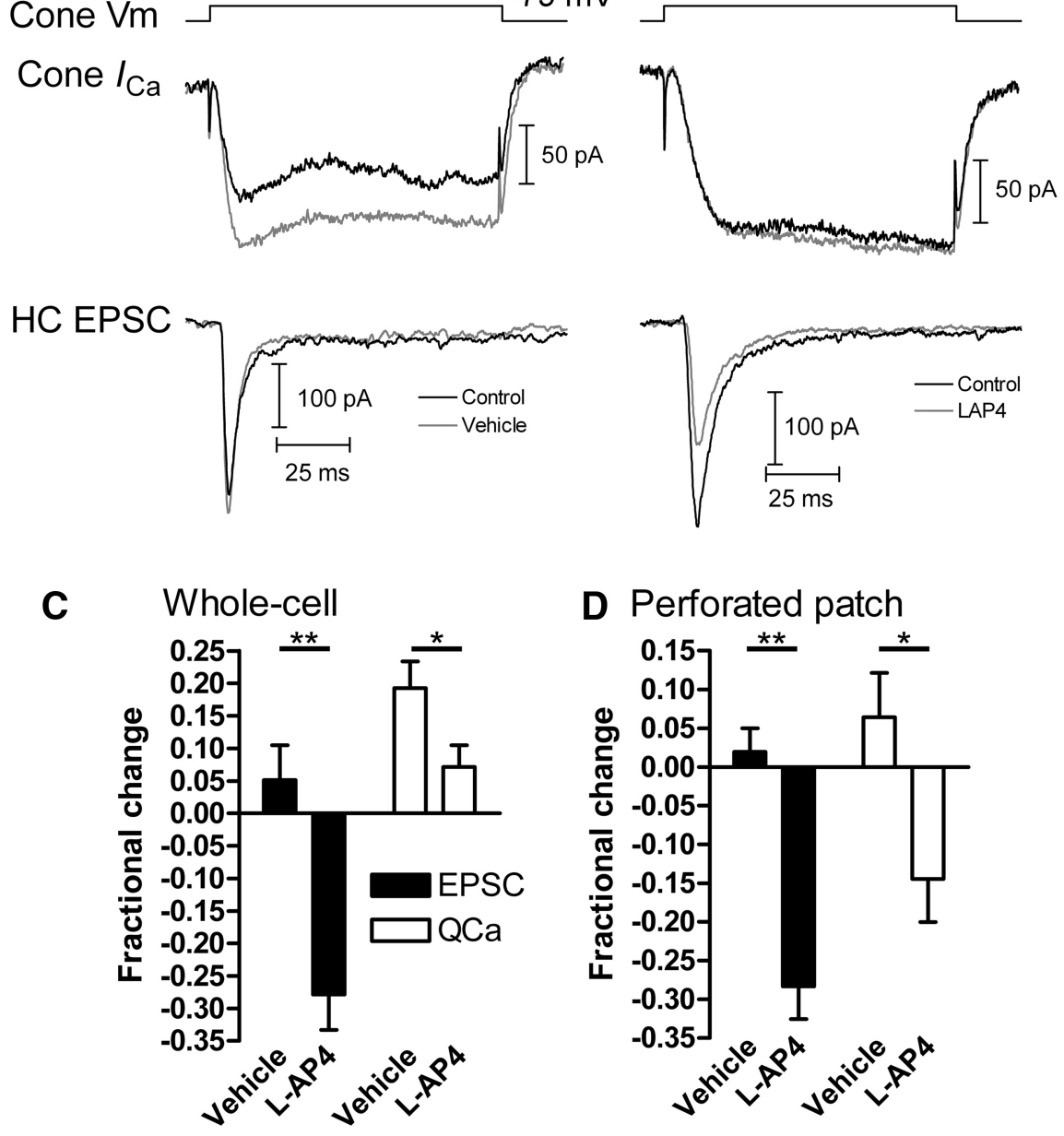

E

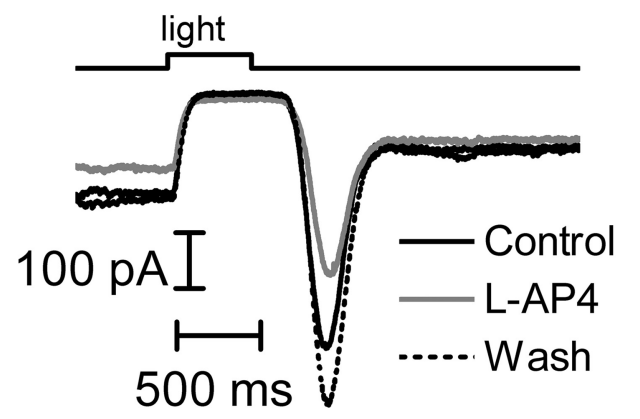

Figure 1. Group III mGluR activation reduces cone synaptic transmission. A, Paired whole-cell recording from a cone and a postsynaptic $\mathrm{HC}$ in a vertical slice from salamander retina. In control conditions (black traces), depolarization of the cone $(-79$ to $-19 \mathrm{mV}, 100 \mathrm{~ms}$ ) evoked an inward $\mathrm{Ca}^{2+}$ current $\left(\mathrm{I}_{\mathrm{Ca}_{\mathrm{a}}}\right)$ in the cone and an EPSC in the HC. After addition of vehicle (gray traces), both $\mathrm{I}_{C_{a}}$ and the EPSC amplitude increased slightly due to runup. $\boldsymbol{B}$, In a different cone-HC pair, the Group III mGluR agonist L-AP4 $(100 \mu \mathrm{M})$ caused a decrease in the cone-driven EPSC. C, Group data (mean \pm SEM) showing that, in the presence of L-AP4 $(n=9)$, EPSC amplitude was decreased and the runup of $Q_{C_{a}}$ was reduced relative to vehicle controls $(n=7) .{ }^{*} p<0.05$ (unpaired $t$ tests). ${ }^{* *} p<0.005$ (unpaired $t$ tests). $D$, Similar experiments conducted with amphotericin/gramicidin perforated patch recordings from cones to minimize runup of either $\mathrm{Q}_{\mathrm{Ca}_{\mathrm{a}}}$ or quantal amplitude showing that L-AP4 caused a reduction in both EPSC and $\mathrm{Q}_{\mathrm{Ca}_{\mathrm{a}}}(n=6)$ relative to vehicle controls $(n=5) .{ }^{*} p<0.05$ (unpaired $t$ test). ${ }^{* *} p<0.005$ (unpaired $t$ test). $\boldsymbol{E}$, L-AP4 caused a small outward current in a voltage-clamped $\mathrm{HC}\left(\mathrm{V}_{\text {hold }}=-69 \mathrm{mV}\right)$, reduced the amplitude of the outward current evoked at light onset, and reduced the inward current at light onset.

synaptic immunoprecipitated, and the antibody detects a single $\sim 25-27$ kDa band on Western blots (Honer et al., 1993; Thompson et al., 1998; Gottschall et al., 2010). G $\beta$ was detected with a rabbit polyclonal antibody (Santa Cruz Biotechnology T-20, RRID:AB_631542, 1:500 dilution). A goat polyclonal antibody raised against CtBP2 (Santa Cruz Biotechnology E-16, RRID:AB_2086774, 1:150 dilution) was used to detect synaptic ribbons.

To probe for protein-protein interactions of SNAP-25 and G $\beta \gamma$, we used the Duolink in situ PLA (Sigma) according to the manufacturer's protocol. Briefly, after overnight incubation with the rabbit-anti-G $\beta$ (1:2500 dilution), mouseanti-SNAP-25 (1:1000 dilution), and goat-antiCtBP2 (1:150 dilution), sections were processed for CtBP2 immunohistochemistry, as above. They were then washed and incubated with PLA probes diluted $1: 5$ at $37^{\circ} \mathrm{C}$ in a humidified chamber. After another wash, the tissue was incubated with the ligation solution and ligase for $30 \mathrm{~min}$ at $37^{\circ} \mathrm{C}$ in a humidified chamber. They were then washed again and incubated with an amplification solution containing polymerase and fluorescently labeled oligonucleotides for $100 \mathrm{~min}$ at $37^{\circ} \mathrm{C}$ in a humidified chamber. Samples were washed a final time, allowed to dry, and coverslipped with the Duolink In Situ Mounting Medium. As negative controls for PLA, the SNAP-25 antibody was omitted from samples run simultaneously as experimental samples.

Images were acquired on a Nikon E600FN microscope equipped with a Yokogawa spinning disk laser confocal scan head (PerkinElmer Ultraview LCA) and a cooled CCD camera (Orca ER) with NIS Elements software (Nikon; RRID: SCR_014329). AlexaFluor-488 was excited with a $488 \mathrm{~nm}$ laser and AlexaFluor-568, and the fluorescently labeled PLA oligonucleotides were excited with a $561 \mathrm{~nm}$ laser. Displayed images are maximum-intensity projections from a series of $z$-sections. Images were acquired using identical settings from experimental and control samples. Brightness and contrast were adjusted uniformly within and between the images for experimental and control samples. PLA puncta were counted in thresholded images using the "analyze particles” feature of ImageJ (RRID:SCR_003070), which detects isolated continuous objects in the image. Neither PLA puncta size nor circularity was constrained for detection. Puncta were detected in regions of interest drawn around each of the retinal layers, as identified in bright-field images and by immunohistochemical staining for CtBP2.

\section{Results}

To test the ability of mGluR to regulate synaptic transmission from photoreceptors and study the mechanisms underlying this regulation, we made paired whole-cell recordings of cones and second-order HCs in vertical slices of salamander retina (Fig. $1 A-$ $C)$. In these recordings, we measured leaksubtracted $\mathrm{Ca}^{2+}$ currents $\left(\mathrm{I}_{\mathrm{Ca}}\right)$ in cones in response to a depolarizing step $(-79$ to -19 $\mathrm{mV}$ ) while simultaneously measuring EPSCs in HCs $\left(\mathrm{V}_{\text {hold }}=-69 \mathrm{mV}\right)$. This depolarizing step simulates the depolarization occurring at termination of a bright flash of light. Following application of the Group III mGluR agonist L-AP4 (100 $\mu \mathrm{M})$, EPSC amplitude was reduced by $28 \pm 5 \%(n=9 ; p=0.007$, paired $t$ test $)$. In 
contrast to effects on the EPSC, $\mathrm{I}_{\mathrm{Ca}}$ was not significantly changed following application of L-AP4 ( $7 \pm 3 \%$ increase; $p=0.11$, paired $t$ test). In vehicle controls, however, we saw a $5 \pm 5 \%$ increase in EPSC amplitude and $19 \pm 4 \%$ increase in $\mathrm{Q}_{\mathrm{Ca}}$. The increase in both EPSC amplitude and $\mathrm{Ca}^{2+}$ influx reflects a gradual runup over the course of these recordings. The runup in $\mathrm{I}_{\mathrm{Ca}}$ is likely due to gradual diffusion of $\mathrm{Cs}^{+}$and TEA into the terminal, which block outward potassium currents, whereas the runup in EPSC amplitude is due to an increase in quantal amplitude that results from inclusion of glutamate in the cone patch pipette solution (Bartoletti and Thoreson, 2011). Correcting for this runup by subtracting $5 \%$ from the relative EPSC amplitude change and $19 \%$ from the $\mathrm{Q}_{\mathrm{Ca}}$ change gives an estimated $\sim 33 \%$ reduction in EPSC amplitude and an estimated $\sim 12 \%$ reduction in $\mathrm{Ca}^{2+}$ influx following application of L-AP4.

To verify this result under conditions that prevent whole-cell dialysis-dependent runup, we made perforated patch recordings from cones while making conventional whole-cell recordings from postsynaptic HCs (Fig. 1D). In these experiments, L-AP4 caused a $14 \pm 5 \%$ decrease in $\mathrm{Q}_{\mathrm{Ca}}(n=6 ; p=0.036$, paired $t$ test $)$ and a $28 \pm 4 \%$ decrease in EPSC amplitude $(n=6 ; p=0.00029$, paired $t$ test). With vehicle controls, in contrast, there was a nonsignificant $2 \pm 3 \%$ increase in EPSC amplitude $(n=5, p=0.25$, paired $t$ test $)$ and a nonsignificant $3 \pm 6 \%$ increase in $\mathrm{Q}_{\mathrm{Ca}}(n=4$, $p=0.45$, paired $t$ test).

Although several studies have pointed to decreases in photoreceptor synaptic transmission following L-AP4 application (Nawy et al., 1989; Hirasawa et al., 2002; Hosoi et al., 2005), others have shown either no effect (Slaughter and Miller, 1981) or examples of L-AP4 increasing the responses of Off-responding retinal neurons (Arkin and Miller, 1987). In darkness, photoreceptors are relatively depolarized and tonically release glutamate onto postsynaptic neurons. Light-evoked hyperpolarization reduces the rate of glutamate release. Consistent with a reduced synaptic drive from cones due to activation of presynaptic mGluRs, the outward current evoked in HCs at light onset was reduced to $79 \pm 16 \%$ of control in the presence of L-AP4 $(n=10$, $p=0.014$, Wilcoxon; Fig. $1 E$ ). The phasic inward current at light offset, which reflects exocytosis of ribbon-associated synaptic vesicles from cones (Jackman et al., 2009), was reduced (69 \pm $11 \%$ of control; $n=13 ; p=0.022$, Wilcoxon).

In darkness, tonic synaptic drive from photoreceptors can be detected as miniature quantal EPSCs in HCs (Fig. 2A-C). Consistent with a role for $\mathrm{mGluR}$ activation in reducing photoreceptor synaptic output, L-AP4 also caused a reduction in HC mEPSC frequency, from $125 \pm 11 \mathrm{~Hz}$ to $97 \pm 13 \mathrm{~Hz}(n=7, p=0.0073$, paired $t$ test). Unlike a previous study of L-AP4 effects on carp HCs, where L-AP4 application was accompanied by a small reduction in mEPSC amplitude (Hirasawa et al., 2002), we did not observe any significant change in mEPSC amplitude in our experiments (control: $8.0 \pm 0.7 \mathrm{pA}$; L-AP4: $7.6 \pm 0.5 \mathrm{pA}, n=7, p=$ 0.42 , paired $t$ test). L-AP4 also did not affect mEPSC kinetics; the $10 \%-90 \%$ rise time was nearly identical in both control and L-AP4 (control: $1.4 \pm 0.11 \mathrm{~ms}$; L-AP4: $1.4 \pm 0.12 \mathrm{~ms} ; n=7, p=$ 0.9979 , paired $t$ test), as was the decay time constant (control: $2.27 \pm 0.25 \mathrm{~ms}$; L-AP4: $2.25 \pm 0.20 \mathrm{~ms} ; n=7, p=0.90$, paired $t$ test).

We next recorded presynaptic glutamate transporter currents arising from fusion of single vesicles using a pipette solution with thiocyanate $\left(\mathrm{SCN}^{-}\right)$as the major anion (Fig. $2 C, D$ ) (Picaud et al., 1995a, b; Szmajda and Devries, 2011; Grabner et al., 2015). SCN ${ }^{-}$is a more permeant anion for glutamate transporters and thereby enhances the amplitude of quantal transporter currents (Szmajda and Devries, 2011; Grabner et al., 2015). In darkness, AMPA receptor- mediated mEPSCs are the result of glutamate release from both rods and cones that is both $\mathrm{Ca}^{2+}$-dependent (due to opening of voltagegated $\mathrm{Ca}^{2+}$ channels and $\mathrm{Ca}^{2+}$-induced $\mathrm{Ca}^{2+}$ release) and $\mathrm{Ca}^{2+}$ independent (Maple et al., 1994; Cork et al., 2016). When cones are voltage-clamped to minimize $\mathrm{Ca}^{2+}$ channel opening, spontaneous release appears to be entirely $\mathrm{Ca}^{2+}$-independent (Cork et al., 2016). Measuring glutamate transporter currents in voltage-clamped cones allowed us to examine these $\mathrm{Ca}^{2+}$-independent vesicle fusion events from the voltage-clamped cone. In vehicle controls, we detected events with an average amplitude of $8.5 \pm 0.9 \mathrm{pA}$ and a frequency of $17.7 \pm 1.4 \mathrm{~Hz}(n=9)$. In cones treated with L-AP4, the frequency was $16.4 \pm 1.0 \mathrm{~Hz}$, which was not significantly different from vehicle ( $p=0.46$, unpaired $t$ test, $n=11$ ). The event amplitude was also not significantly different in L-AP4-treated cones $(9.0 \pm 0.8 \mathrm{pA}, n=11$, $p=0.68$, unpaired $t$ test).

Although L-AP4 did not reduce $\mathrm{Ca}^{2+}$-independent spontaneous glutamate release, application of L-AP4 did reduce the amplitude of glutamate transporter currents evoked by a depolarizing stimulus (Fig. 2E). In L-AP4-treated cones, a 20 ms depolarization (with a P/8 leak subtraction protocol) evoked a $174 \pm 35 \mathrm{pA}$ current $(n=9)$, which was significantly smaller than the $313 \pm 37$ pA current evoked in vehicle controls $(n=8, p=0.016$, unpaired $t$ test). Thus, our results point to a role of Group III mGluRs in regulating $\mathrm{Ca}^{2+}$. dependent, but not $\mathrm{Ca}^{2+}$-independent, exocytosis from cones. The ability of mGluRs to inhibit release from cones is consistent with previous work in fish (Nawy et al., 1989; Hirasawa et al., 2002) and amphibian retina (Hosoi et al., 2005).

The ability to modulate release with the exogenously applied glutamate agonist L-AP4 suggests that glutamate released into the synaptic cleft during darkness does not saturate presynaptic mGluRs on cones. To test whether cleft glutamate has a meaningful impact on cone synaptic output in darkness, we next blocked mGluR signaling using the Group III mGluR antagonist CPPG (50 $\mu \mathrm{M}$; Fig. $2 F, G)$. Consistent with mGluR-dependent tonic inhibition of synaptic vesicle exocytosis in darkness, CPPG caused a small but significant increase in the frequency of mEPSCs observed in HCs (from $98 \pm 3$ to $111 \pm 3 \mathrm{~Hz} ; n=11 ; p=0.0078$, paired $t$ test) without affecting mEPSC amplitude (control $=8.5 \pm 0.5 \mathrm{pA} ; \mathrm{CPPG}=8.6 \pm 0.6 \mathrm{pA}$; $n=11 ; p=0.82$, paired $t$ test).

To explore the functional impact of mGluR signaling during a more complex time-varying light stimulus, we next recorded HC light responses to a $2 \mathrm{~Hz}$ square-wave white light stimulus train (1100 Lux, 20 s duration; Fig. 3). Because mGluR activation with $\mathrm{L}-\mathrm{AP} 4$ reduced light responses, one might expect CPPG to have the opposite effect. Instead, in these experiments, CPPG significantly reduced the light response power measured at $2 \mathrm{~Hz}$ from $4.3 \pm 0.2$ to $3.5 \pm 0.3 \log \left(\mathrm{pA}^{2} / \mathrm{Hz}\right)(p=0.00028$, paired $t$ test; $n=16$ ). This result supports a role for mGluRs in shaping lightresponse encoding across the cone synapse, which might be attributable to mGluRs preventing vesicle pool depletion, as proposed previously (Hosoi et al., 2005).

A previous study on the role of Group III mGluRs in cones showed that application of L-AP4 caused a modest decrease in $\mathrm{Q}_{\mathrm{Ca}}(\sim 15 \%)$ at the peak of the $I-V$ curve $(-20 \mathrm{mV})$ and a $30 \%-$ $50 \%$ decrease in synaptic transmission to second-order neurons (Hosoi et al., 2005). The mismatch in L-AP4 effects on synaptic transmission and $\mathrm{Ca}^{2+}$ influx is notable, as studies of the $\mathrm{Ca}^{2+}$ dependence of synaptic vesicle exocytosis from cones have indicated that the exocytotic $\mathrm{Ca}^{2+}$ sensor has a cooperativity of $n=$ 1-2 (Thoreson et al., 2004; Duncan et al., 2010). Moreover, our previous work studying the effects of intracellular $\mathrm{Ca}^{2+}$ buffering in cones (Bartoletti et al., 2011; Mercer et al., 2011; Van Hook and Thoreson, 2014, 2015) has suggested that phasic exocytosis is 
A Horizontal cell mEPSCs

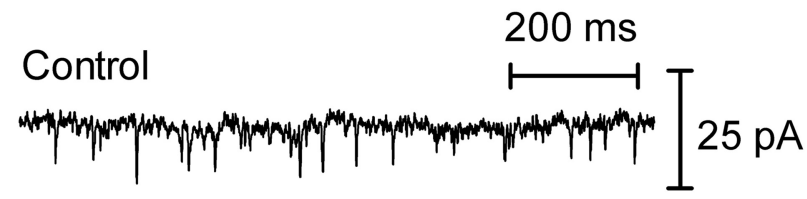

L-AP4

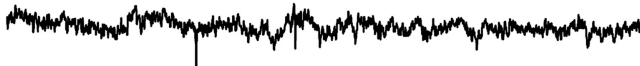

C Cone glutamate transporter currents

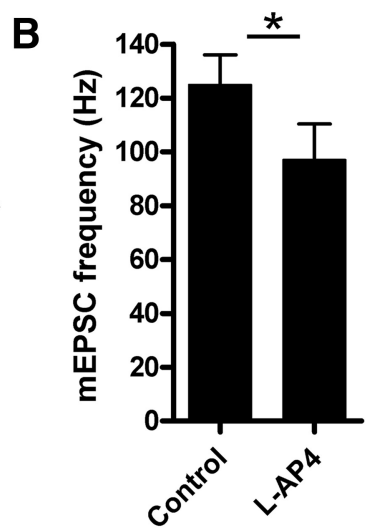

D E

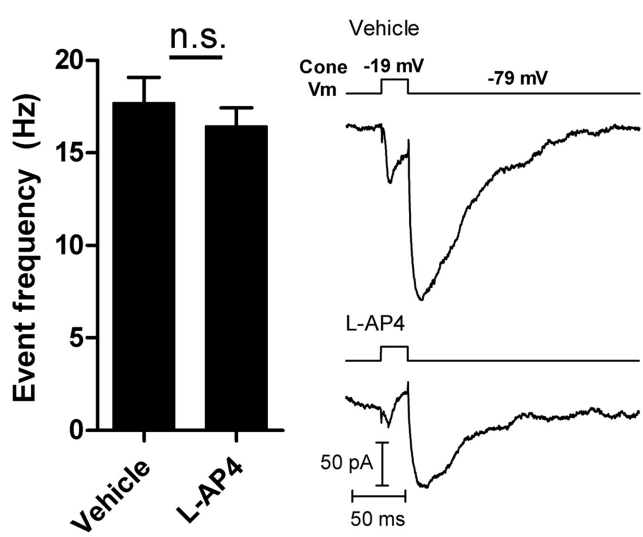

G

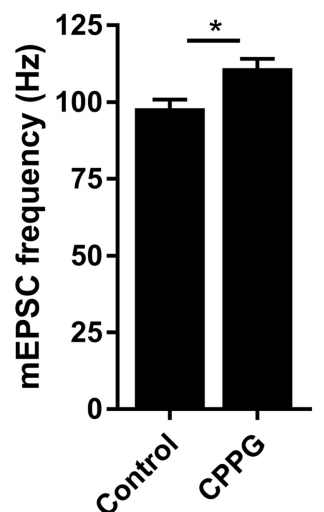

Figure 2. $\mathrm{mGluR}$ activation reduces $\mathrm{Ca}^{2+}$-dependent quantal release from cones. $A$, Voltage-clamp recording of $\mathrm{mEPSCs}$ from an $\mathrm{HC}\left(\mathrm{V}_{\text {hold }}=-69 \mathrm{mV}\right)$ in a vertical slice of salamander retina in control conditions and in the presence of L-AP4 $(100 \mu \mathrm{m})$. L-AP4 caused a reduction in mEPSC frequency. B, Group data (mean + SEM) of mEPSC frequency showing that L-AP4 caused a reduction in event frequency without affecting amplitude or event kinetics $(n=7 \mathrm{HCs}) .{ }^{*} p<0.05$ (paired $t$ test). $C$, Voltage-clamp recordings from cones showing glutamate transporter anion currents evoked presynaptically by spontaneous exocytosis of synaptic vesicles. A potassium thiocyanate intracellular solution was used to enhance the amplitude of anion transporter currents. Traces show events recorded from different cones in vehicle controls and L-AP4 $(100 \mu \mathrm{M})$. D , Group data (mean + SEM) showing that L-AP4 had no significant effect on event frequency. Not significant, $p>0.05$ (unpaired $t$ test). Vehicle controls, $n=9$ cones; L-AP4 $(100 \mu \mathrm{M}), n=11$ cones. $E$, Glutamate transporter currents evoked by a $25 \mathrm{~ms}$ depolarizing step $(-79$ to $-19 \mathrm{mV}, \mathrm{P} / 8$ leak-subtracted) in two different cones in the presence of vehicle or $100 \mu \mathrm{m} \mathrm{L-AP4}$. Despite causing no change in quantal amplitude or frequency of $\mathrm{Ca}^{2+}$-independent spontaneous release events (C), L-AP4 caused a significant reduction in evoked transporter currents. ${ }^{*} p<0.05$ (unpaired $t$ test). $F$, Voltage-clamp recording of $\mathrm{mEPSCs}$ from an $\mathrm{HC}\left(\mathrm{V}_{\text {hold }}=-69 \mathrm{mV}\right.$ control conditions and in the presence of 50 $\mu \mathrm{M}(\mathrm{PPG}) . \mathbf{G}, \mathrm{CPPG}$ caused an increase in mEPSC frequency $(n=11 \mathrm{HC}) .{ }^{*} p<0.05$ (paired $t$ test).

triggered by $\mathrm{Ca}^{2+}$ nanodomains, which could also give rise to linear $\mathrm{Ca}^{2+}$ dependence of synaptic vesicle exocytosis (Eggermann et al., 2011). The unconventionally low $\mathrm{Ca}^{2+}$ cooperativity of the cone $\mathrm{Ca}^{2+}$ sensor and evidence for nanodomain control of exocytosis suggest that a reduction in $\mathrm{Ca}^{2+}$ influx should lead to a similar reduction in exocytosis. This contrasts with both our results and those of Hosoi et al. (2005), where the reduction in exocytosis appeared to be twofold to fourfold greater than the reduction in $\mathrm{I}_{\mathrm{Ca}}$.

To verify that cone exocytosis is indeed linearly correlated with $\mathrm{Ca}^{2+}$ influx, we used an approach that has previously been used to study the $\mathrm{Ca}^{2+}$ dependence of exocytosis by inner hair 
cells (Goutman and Glowatzki, 2007). In these experiments (Fig. 4A), we recorded EPSCs in HCs while evoking synaptic vesicle exocytosis from cones with steps to $-29,-19,-9,1,11$, or $21 \mathrm{mV}$ from a holding potential of $61 \mathrm{mV}$ so that the $\mathrm{Ca}^{2+}$ conductance was maximally activated and the only effect of voltage was to change the $\mathrm{Ca}^{2+}$ driving force. In these recordings ( $n=8$ cone-HC pairs), EPSC amplitude changed in proportion to $\mathrm{I}_{\mathrm{Ca}}$ (measured using a $\mathrm{P} / 8$ leak-subtracted ramp protocol from -99 to $51 \mathrm{mV}$ at 0.5 $\mathrm{mV} / \mathrm{ms})$. When we plotted the EPSC amplitude as a function of $\mathrm{I}_{\mathrm{Ca}}$ (Fig. $4 B$ ), the two exhibited a strong linear correlation $\left(r^{2}=0.98, p=0.0002\right.$, Pearson correlation). This confirms that exocytosis in cones is linearly correlated with the local $\mathrm{Ca}^{2+}$ influx, a result stemming from low cooperativity of the $\mathrm{Ca}^{2+}$ sensor (Thoreson et al., 2004; Duncan et al., 2010; Bartoletti et al., 2011; Van Hook and Thoreson, 2015).

Thus, our data support a role for a Group III mGluR in regulating synaptic transmission by cone photoreceptors, in concert with previous work (Nawy et al., 1989; Hirasawa et al., 2002; Hosoi et al., 2005). The linear dependence of exocytosis on $\mathrm{Ca}^{2+}$ influx suggests that a mechanism downstream of $\mathrm{Ca}^{2+}$ entry contributes to the decrease in synaptic transmission. $\mathrm{G} \beta \gamma$ is a likely candidate to mediate this effect, as previous studies in lamprey and rodent neurons have revealed that $\mathrm{G} \beta \gamma$ can bind directly to components of the SNARE complex to inhibit exocytosis downstream of $\mathrm{Ca}^{2+}$ influx (Blackmer et al., 2001, 2005; Gerachshenko et al., 2005; Yoon et al., 2007; Wells et al., 2012). Current evidence indicates that this is largely the result of interactions of the $\mathrm{G} \beta \gamma$ complex with amino acids located on the C terminus of SNAP-25 (Blackmer et al., 2001, 2005; Gerachshenko et al., 2005; Yoon et al., 2007; Wells et al., 2012), although other components such as syntaxin also appear to bind $\mathrm{G} \beta \gamma$ (Yoon et al., 2007; Wells et al., 2012; Zurawski et al., 2016).

To examine localization of the G $\beta \gamma$ complex and SNAP-25 in salamander retina, we stained $30 \mu \mathrm{m}$ retinal sections with antibodies against G $\beta$ and SNAP-25 (Fig. 5A). We found strong G $\beta$ labeling in photoreceptor outer segments as expected from its association with opsin, as well as labeling in the outer plexiform layer (OPL). SNAP-25 labeling was detected strongly in the IPL and OPL, as expected from its function in synaptic vesicle fusion. There are conflicting reports about whether SNAP-25 is expressed at cone photoreceptor synapses (Catsicas et al., 1992; Ullrich and Südhof, 1994; Brandstätter et al., 1996; Grabs et al., 1996; Greenlee et al., 2001; Hirano et al., 2011). Therefore, we sought to confirm its presence in cone synaptic terminals by staining isolated cone photoreceptors with an antibody sensitive to SNAP-25 (Fig. 5B). In these experiments, robust SNAP-25 staining was detected at cone terminals. Terminals were identified by staining for synaptic ribbons with an antibody raised against CtBP2. Although cone outer segments were lost in these isolated cells, we did detect some SNAP-25 labeling throughout inner segments, which is consistent with expression of SNAP-25 on the Golgi and a role for SNARE proteins in intracellular transport (Morgans and Brandstätter, 2000; Mazelova et al., 2009; Zulliger et al., 2015). We also performed double immunostaining for SNAP-25 and G $\beta$ in isolated cones (Fig. $5 C$ ). In these cells, $G \beta$ was detected throughout the cell, and strongly at the synaptic terminal, along with SNAP-25. To test for protein-protein interactions between the G $\beta \gamma$ complex and SNAP-25, we used the
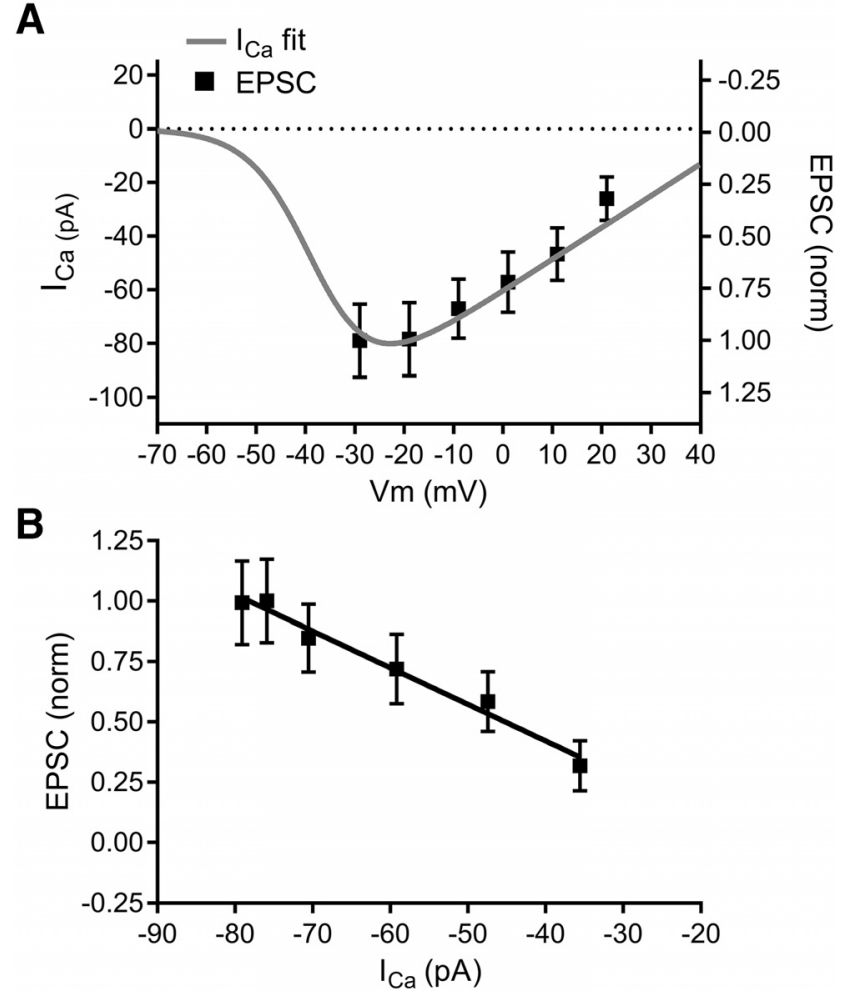

Figure 4. Synaptic vesicle exocytosis is linearly correlated with $\mathrm{Ca}^{2+}$ influx at the cone synapse. $A$, Overlaid plots of $\mathrm{I}_{\mathrm{Ca}}$ and EPSCs. $\mathrm{I}_{\mathrm{Ca}}$ (gray line) is plotted as the reversal potentialcorrected Boltzmann fit of the average cone membrane current recorded from $n=8$ cones with a P/8 leak subtraction protocol ( -99 to $+51 \mathrm{mV}$ ramp, $0.5 \mathrm{mV} / \mathrm{ms}$ ). EPSC amplitudes (black square) are mean \pm SEM of normalized EPSCs recorded in cone-HC pairs in which the cone was held near the $\mathrm{Ca}^{2+}$ reversal potential $(61 \mathrm{mV})$ before being stepped down to a variety of test potentials ( -29 to $21 \mathrm{mV}$ ) to evoke an EPSC ( $n=8$ cone-HC pairs). $\boldsymbol{B}$, Replotting of data from A showing normalized EPSCS plotted against the $\mathrm{I}_{\mathrm{C} \text {. }}$. The relationship was well fit with a straight line $\left(r^{2}=0.98, p=0.0002\right.$, Pearson correlation), showing that exocytosis is linearly related to the amount of $\mathrm{Ca}^{2+}$ influx.

PLA after incubating $30 \mu \mathrm{m}$ retinal sections with both $\mathrm{G} \beta$ and SNAP-25 antibodies. In retinal sections (Fig. 5D-G), there was PLA signal (red puncta) present in the OPL, the location of photoreceptor synaptic terminals (indicated by CtBP2 staining), as well as in the ganglion cell layer, inner plexiform layer, and photoreceptor outer segments. The density of PLA puncta varied with retinal layers (Fig. $5 E ; n=4$ sections), with the highest density in the IPL $\left(11.0 \pm 2.3 / 100 \mu \mathrm{m}^{2}\right)$. There was also a band of PLA puncta in the OPL $\left(4.1 \pm 0.8 / 100 \mu \mathrm{m}^{2}\right)$, higher than in the 

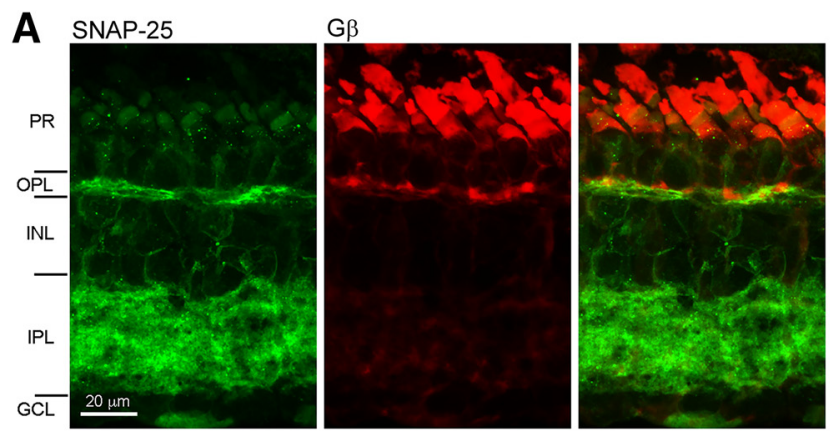

B
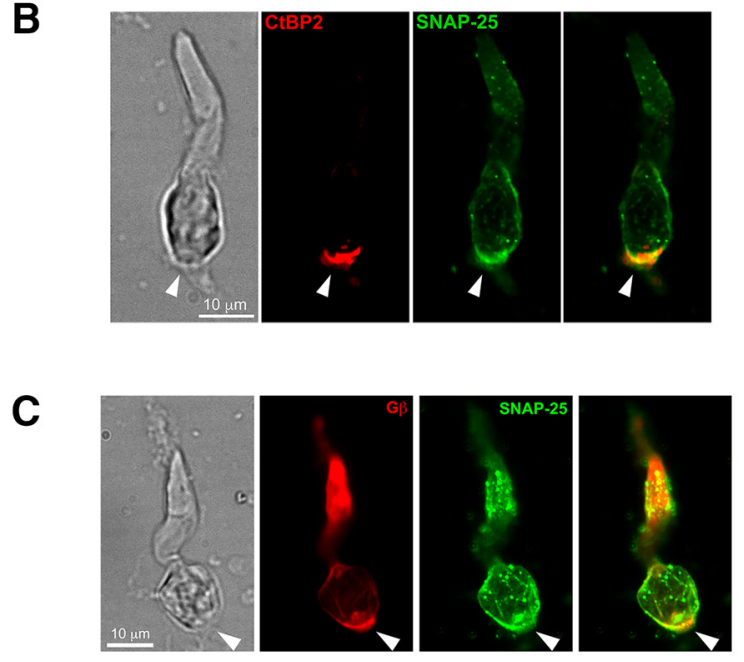

D

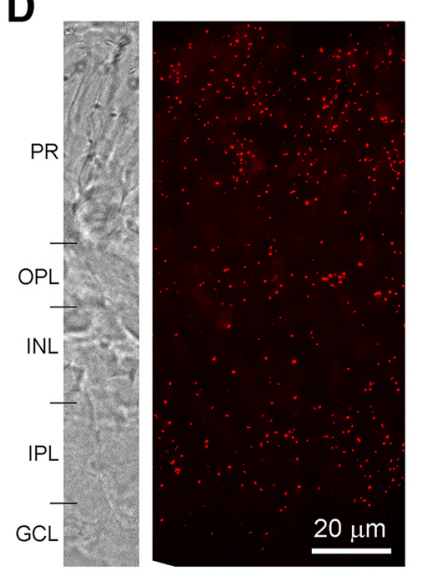

$\mathbf{F}$

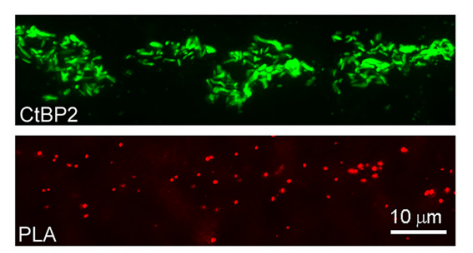

G

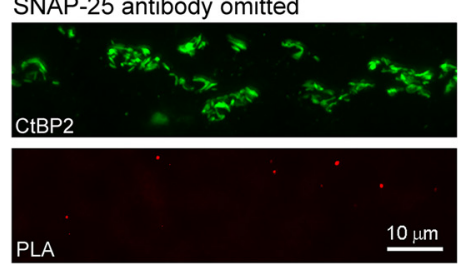

Figure 5. Localization and interactions of the $G \beta \gamma$ complex and SNAP-25. $A$, The $30 \mu \mathrm{m}$ vertical section of a salamander retina showing staining for SNAP- 25 (green) and G $\beta$ (red). SNAP-25 staining is especially apparent in the OPL and IPL, and G $\beta$ staining is present in photoreceptor outer and inner segments and in the OPL. $\boldsymbol{B}$, Staining of an isolated cone photoreceptor for synaptic ribbons (CtBP2, red) and SNAP-25 (green) showing strong signal for both in the cone synaptic terminal (arrowhead). C, Staining of an isolated cone for G $\beta$ (red) and SNAP-25 (green), showing labeling throughout the cell, including in the synaptic terminal (arrowhead). D, PLA for G $\beta$ and SNAP-25 interactions shows strong PLA signal (red puncta) throughout the retina, including in the OPL. E, Density of PLA puncta ( $n=4$ retinal sections) measured in different retinal layers (black bars) and in negative control ( $n=3$ retinal sections) experiments in which the SNAP-25 antibody was omitted (white bars). $\boldsymbol{F}$, (ropped image of the OPL showing immunohistochemical staining for synaptic ribbons (CtBP2, green) and PLA signal for SNAP-25/G $\beta$ interactions (red). G, The PLA signal was nearly abolished when the SNAP-25 antibody was omitted.

neighboring INL $\left(2.9 \pm 0.7 / 100 \mu \mathrm{m}^{2} ; p=0.008\right)$ or photoreceptor inner segments $\left(1.8 \pm 0.7 / 100 \mu \mathrm{m}^{2} ; p=0.012\right)$. When we omitted the SNAP-25 antibody as a negative control $(n=3 \mathrm{sec}-$ tions; Fig. $5 G$ ), the PLA signal was nearly abolished. This confirms that $\mathrm{G} \beta \gamma$ and SNAP-25 directly interact with one another in the OPL, as well as other regions of retina.

Having found G $\beta \gamma$-SNAP-25 interactions in the OPL, we next used two complementary approaches to test whether this specific interaction contributes to the Group III mGluR-dependent reduction in synaptic transmission by cones (Fig. 6). In the first approach (Fig. 6A), we incubated retinal slices in botulinum neurotoxin A (BoNT/A; $20 \mathrm{~nm}$ ) for 60 min before beginning electrophysiological recordings. BoNT/A cleaves 9 amino acids from the C terminus of SNAP-25 at a fairly well-conserved pair of residues (Q197 and R198) (Schiavo et al., 1993). The surrounding residues are also important for BoNT/A recognition in mammals (Schiavo et al., 1993; Washbourne et al., 1997). Although the tiger salamander SNAP-25 sequence is unknown, this site and the rest of the SNAP-25 C terminus are largely conserved in the Japanese fire belly newt (Cynops pyrrhogaster, GenBank accession \#BAE47569.1), another amphibian related to the tiger salamander. The actions of BoNT/A at this site have been shown to inhibit G $\beta \gamma$-SNAP-25 interactions and G $\beta \gamma$-mediated reductions in synaptic transmission in other neurons (Gerachshenko et al.,
2005; Delaney et al., 2007; Hamid et al., 2014). In recordings from tissue treated with BoNT/A ( $n=5$ cone-HC pairs), L-AP4 application resulted in a nonsignificant $8 \pm 4 \%$ increase in $\mathrm{I}_{\mathrm{Ca}}(p=0.14$, paired $t$ test; $n=5)$ and a nonsignificant $7 \pm 4 \%$ reduction in the EPSC amplitude ( $p=0.17$, paired $t$ test; $n=5)$. After correcting for runup, this corresponded to an estimated $\sim 11 \%$ reduction in $\mathrm{Ca}^{2+}$ influx and a similar $\sim 12 \%$ estimated reduction in EPSC amplitude. Thus, although L-AP4 still caused a reduction in both exocytosis and $\mathrm{I}_{\mathrm{Ca}}$, the two were reduced by a similar fraction, in contrast to L-AP4 treatment in non-BoNT/A-treated tissue.

Surprisingly, EPSC amplitude in BoNT/A-treated cone-HC pairs $(196 \pm 22 \mathrm{pA} ; n=17)$ did not differ significantly from EPSCs recorded in untreated tissue $(231 \pm 28 \mathrm{pA}, n=24, p=$ 0.32 , unpaired $t$ test). There are two factors that likely contribute to this finding. The first is that the amplitude of cone-driven EPSCs across individual cones is highly variable ( range $=48-728$ pA in this sample) and scales with the number of ribbon contacts the cone makes with any given $\mathrm{HC}$ ( $47 \mathrm{pA}$ per ribbon-contact) (Bartoletti et al., 2010). Second, the SNAP-25 C terminus is a site of $\mathrm{Ca}^{2+}$-dependent interaction with synaptotagmin and BoNT/ A-mediated cleavage of the last 9 residues appears to cause a shift in the $\mathrm{Ca}^{2+}$ dependence of that interaction (Otto et al., 1995; Gerona et al., 2000; Humeau et al., 2000). Because our stimulus reaches the peak of the cone $\mathrm{I}_{\mathrm{Ca}}$, the nanodomain of elevated 


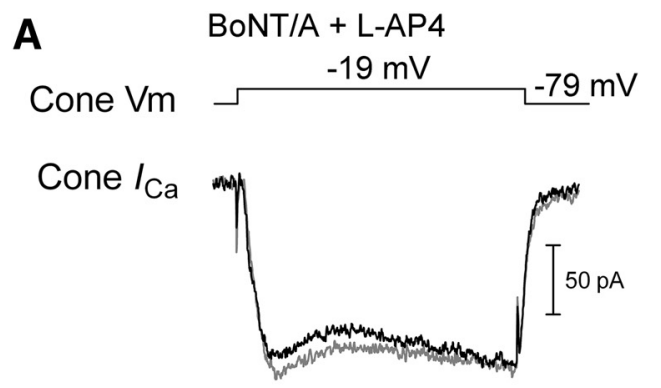

B

HC EPSC
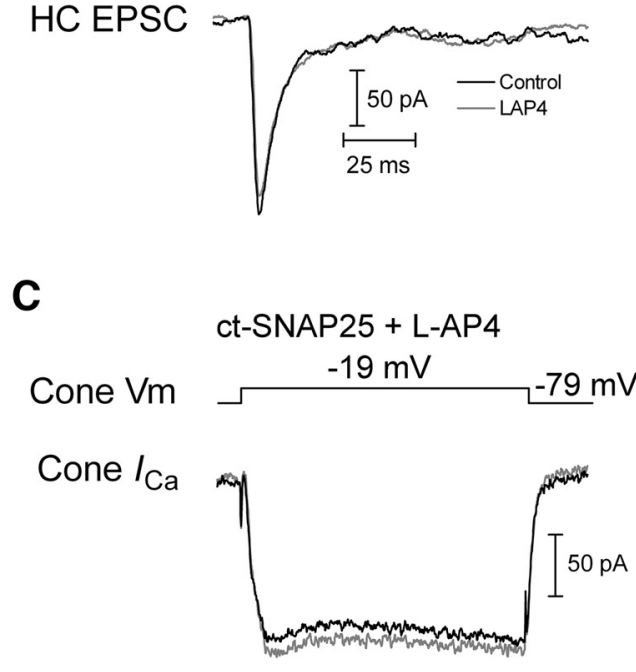

HC EPSC

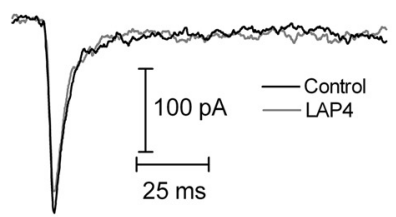

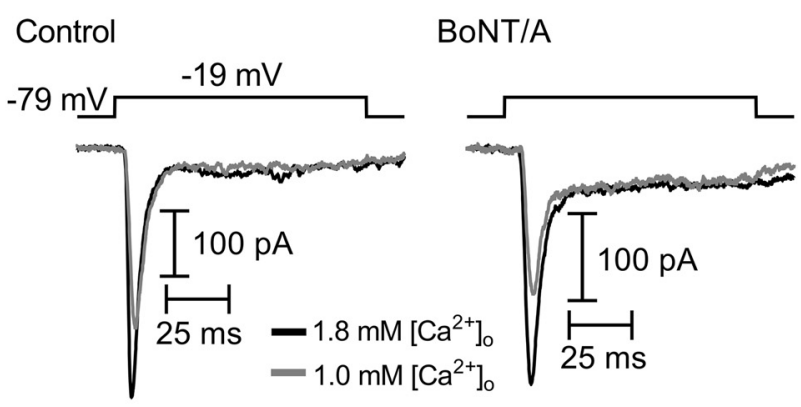

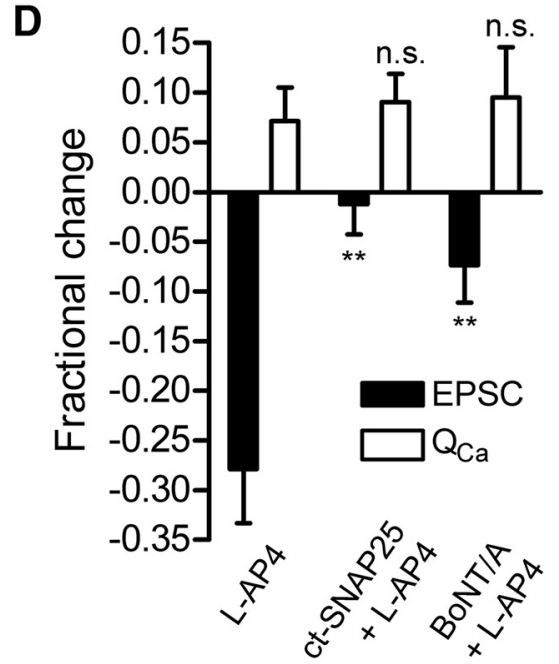

Figure 6. mGluR-mediated inhibition of exocytosis involves the SNAP- 25 C terminus. A, Paired voltage-clamp recording of a cone and a HC in which retinal slices were pretreated with $20 \mathrm{nM}$ BoNT/A for $1 \mathrm{~h}$ before beginning recordings. $\mathrm{I}_{\mathrm{C}}$ runs up slightly following L-AP4 application and the EPSC is slightly reduced. $\boldsymbol{B}$, Left, Slices were incubated in amphibian saline solution for $1 \mathrm{~h}$ before beginning recording (control). Right, Slices were incubated with $20 \mathrm{~nm}$ BoNT/A for $1 \mathrm{~h}$ before beginning recording (BoNT/A). In paired voltage-clamp recordings of a cone and a $\mathrm{HC}$, switching from the standard amphibian saline solution containing $1.8 \mathrm{~mm} \mathrm{Ca}^{2+}$ to a solution containing $1.0 \mathrm{~mm} \mathrm{Ca}^{2+}$ reduced the EPSC. When slices were treated with BoNT/A, the reduction in EPSC amplitude was greater following application of the $1.0 \mathrm{~mm} \mathrm{Ca}{ }^{2+}$ solution. C, Paired cone/HC voltage-clamp recording in which the cone patch pipette solution contained the ct-SNAP-25 peptide (1 $\left.\mu \mathrm{m}\right)$ in control conditions (black) and in the presence of L-AP4 (100 $\mu \mathrm{m}$, gray). I Ca $_{\text {a }}$ ran up slightly following L-AP4 application, and the EPSC was slightly reduced. $\boldsymbol{D}$, Group data (mean + SEM) showing the effects of L-AP4 (normalized to preL-AP4 controls) when the cone patch pipette contained the ct-SNAP-25 peptide ( $n=7$ cone-HC pairs) or when slices were pretreated with BoNT/A ( $n=5$ cone-HC pairs). The L-AP4 data ( $n=9$ cone-HC pairs) are replotted from Figure 1 for comparison with ct-SNAP-25 and BoNT/A experiments. The effect of L-AP4 was significantly reduced in ct-SNAP-25 or BoNT/A conditions, whereas $\mathrm{Ca}^{2+}$ influx was unaffected. ${ }^{* *} p<0.005$ (unpaired $t$ tests). Not significant, $p>0.05$ (unpaired $t$ tests).

intracellular $\left[\mathrm{Ca}^{2+}\right]$ might be sufficient to overcome the effect of BoNT/A (Gerona et al., 2000; Humeau et al., 2000). We tested this possibility by recording cone-driven EPSCs when $\left[\mathrm{Ca}^{2+}\right]_{\mathrm{o}}$ was reduced from $1.8 \mathrm{~mm}$ to $1.0 \mathrm{~mm}$ to reduce the concentration of $\mathrm{Ca}^{2+}$ attained in nanodomains beneath open $\mathrm{Ca}^{2+}$ channels (Fig. 6B). In slices treated with BoNT/A, switching from 1.8 to 1.0 $\mathrm{mM}\left[\mathrm{Ca}^{2+}\right]_{\mathrm{o}}$ reduced EPSC amplitude by $41 \pm 7 \%(n=6)$, a significantly greater reduction than occurred in control (nonBoNT/A) slices (19 $\pm 5 \%, n=6 ; p=0.03)$. This verifies that BoNT/A is effective at salamander cone synapses and is consistent with previous reports indicating that high $\left[\mathrm{Ca}^{2+}\right]$ can overcome the BoNT/A-mediated reduction in exocytosis (Gerona et al., 2000; Humeau et al., 2000).

In another set of experiments, we introduced a 14 amino acid peptide matching the $\mathrm{C}$ terminus of SNAP-25 into the cone through the patch pipette (ct-SNAP-25; Fig. 6C). This region of SNAP- 25 was shown to be important for $\mathrm{G} \beta \gamma$ binding (Blackmer et al., 2005; Yoon et al., 2007; Wells et al., 2012), and a peptide corresponding to this region prevents $\mathrm{G} \beta \gamma$-mediated inhibition of exocytosis (Gerachshenko et al., 2005). In recordings in which cones were dialyzed with $1 \mu \mathrm{M}$ ct-SNAP-25, $\mathrm{I}_{\mathrm{Ca}}$ was increased by $9 \pm 3 \%(n=7 ; p=0.019$, paired $t$ test $)$ and the EPSC was not significantly changed ( $1 \pm 3 \%$ decrease; $p=0.4$, paired $t$ test $)$ following L-AP4 application (100 $\mu \mathrm{M})$ compared with a $28 \pm 5 \%$ decrease in control. However, if we account for runup of both the EPSC and $\mathrm{I}_{\mathrm{Ca}}$, these values correspond to an estimated $\sim 6 \%$ decrease in EPSC amplitude and an estimated $\sim 10 \%$ decrease in $\mathrm{I}_{\mathrm{Ca}}$. Unlike L-AP4 treatment in control, application of L-AP4 to cones dialyzed with the inhibitory ct-SNAP-25 peptide produced similar decreases in both $\mathrm{I}_{\mathrm{Ca}}$ and EPSC amplitude. Like BoNT/A experiments, this suggests that the ct-SNAP-25 peptide effectively blocks the interaction of $G \beta \gamma$ with the $S+$ or - NARE complex and removes the mGluR effect on EPSCs and that Group III mGluR activation reduces exocytosis both by reduc- 
ing $\mathrm{Ca}^{2+}$ influx and by direct $\mathrm{G} \beta \gamma$-SNAP-25 interactions downstream of $\mathrm{Ca}^{2+}$ influx.

L-AP4 application also caused a small reduction in $\mathrm{Ca}^{2+}$ influx (Fig. 1). $\mathrm{G} \beta \gamma$ is able to reduce $\mathrm{I}_{\mathrm{Ca}}$ by directly interacting with voltage-gated $\mathrm{Ca}^{2+}$ channels, including some L-type channels (Ivanina et al., 2000; Tedford and Zamponi, 2006; Currie, 2010; Farrell et al., 2014). To verify that the $G \beta \gamma$ complex is able to inhibit exocytosis and test for a direct influence of $\mathrm{G} \beta \gamma$ on $\mathrm{I}_{\mathrm{Ca}}$, we made paired whole-cell recordings of cones and HCs and introduced $\mathrm{G} \beta_{1} \gamma_{1}$ complex isolated from bovine rods $(0.1-2 \mu \mathrm{M})$ into the cone through the patch pipette (Fig. 7). In these experiments, we simultaneously measured leak-subtracted $\mathrm{I}_{\mathrm{Ca}}$ in cones and EPSCs in HCs by depolarizing the cone shortly after establishing a whole-cell configuration and every $3 \mathrm{~min}$ for $>20 \mathrm{~min}$ thereafter. As a negative control, we boiled the $\mathrm{G} \beta_{1} \gamma_{1}$ stock solution for $30 \mathrm{~min}$ before diluting it in the cone pipette solution. As shown in Figure $7 C-F$, although $G \beta_{1} \gamma_{1}$ caused a dose-dependent reduction in EPSC amplitude $\left(\mathrm{IC}_{50}=80 \mathrm{nM}\right)$, there was no effect on $\mathrm{I}_{\mathrm{Ca}}$ amplitude. With boiled $\mathrm{G} \beta_{1} \gamma_{1}$, the EPSCs ran up, reaching $131 \pm$ $17 \%$ of the first EPSC 15 min into the recording $(n=7$ cone/HC pairs). The EPSC was reduced to $88 \pm 14 \%(n=4)$ with $100 \mathrm{~nm}$ $\mathrm{G} \beta_{1} \gamma_{1}, 56 \pm 10 \%$ with $300 \mathrm{~nm} \mathrm{G} \beta_{1} \gamma_{1}(n=8)$, and $48 \pm 14 \%$ with $2 \mu \mathrm{M} \mathrm{G} \beta_{1} \gamma_{1}$. $\mathrm{I}_{\mathrm{Ca}}$ ran up to $138 \pm 12 \%$ for the boiled control $(n=5), 142 \pm 12 \%$ for $100 \mathrm{~nm}, 134 \pm 5 \%$ for $300 \mathrm{nM}$, and $124 \pm$ $14 \%$ for $2 \mu \mathrm{M} \mathrm{G} \beta_{1} \gamma_{1}(n=7)$. Because these measurements were taken with a step to the peak of the $\mathrm{I}_{\mathrm{Ca}}$ activation curve $(-19$ $\mathrm{mV}$ ), which might not have revealed $\mathrm{G} \beta_{1} \gamma_{1}$-mediated changes in $\mathrm{I}_{\mathrm{Ca}}$ voltage dependence, we next measured leak-subtracted $\mathrm{I}_{\mathrm{Ca}}$ in cones dialyzed with boiled $\mathrm{G} \beta_{1} \gamma_{1}$ or $300 \mathrm{~nm} \mathrm{G} \beta_{1} \gamma_{1}$ using a series of voltage steps ( -69 to $31 \mathrm{mV}, 10 \mathrm{mV}$ increments). In these experiments (Fig. $7 \mathrm{G}, \mathrm{H}$ ), neither the maximum $\mathrm{Q}_{\mathrm{Ca}}$ nor the voltage dependence was affected by the presence of $\mathrm{G} \beta_{1} \gamma_{1}$ (boiled peak $\mathrm{Q}_{\mathrm{Ca}}: 18 \pm 1 \mathrm{pC}, n=6 ; \mathrm{G}_{1} \gamma_{1}$ peak $\mathrm{Q}_{\mathrm{Ca}}: 18 \pm 1 \mathrm{pC}$ at -19 $\mathrm{mV}, n=5 ; p=0.46$; boiled $\mathrm{V}_{50}=-35 \pm 2 \mathrm{mV}, n=6$; $\mathrm{G} \beta_{1} \gamma_{1}$ $\left.\mathrm{V}_{50}=-36 \pm 1 \mathrm{mV}, n=5 ; p=0.5\right)$. The finding that exogenous $\mathrm{G} \beta_{1} \gamma_{1}$ did not alter $\mathrm{Ca}^{2+}$ channel function suggests that the effects of Group III mGluR activation on $\mathrm{I}_{\mathrm{Ca}}$ are more likely the result of $\mathrm{G} \alpha$-dependent or other signaling pathways downstream of Group III mGluRs.

In a parallel set of experiments (Fig. 8), we used whole-cell $\mathrm{C}_{\mathrm{m}}$ recordings to measure synaptic vesicle exocytosis directly from cones dialyzed with either functional or boiled $\mathrm{G} \beta_{1} \gamma_{1}(300 \mathrm{nM}$ ). Because $\mathrm{C}_{\mathrm{m}}$ recordings provide a measure of changes in membrane surface area resulting from addition of vesicular membrane, they are not prone to runup due to the inclusion of glutamate in the presynaptic patch pipette, which affects quantal content (Bartoletti and Thoreson, 2011). Additionally, because we needed to introduce the large $\mathrm{G} \beta_{1} \gamma_{1}$ protein complex through the patch pipette, we could not use perforated patch recordings for this purpose. When cones were dialyzed with $\mathrm{G} \beta_{1} \gamma_{1}$, the capacitance transient evoked by a $25 \mathrm{~ms}$ depolarizing step (from -79 to $-19 \mathrm{mV})$ was reduced by $53 \pm 5 \%(n=6)$ relative to the first response within $8-12$ min of whole-cell recording $(p=$ 0.0029 , paired $t$ test). In contrast, when the cone was dialyzed with boiled $\mathrm{G} \beta_{1} \gamma_{1}$, the depolarization-evoked capacitance response was relatively unchanged after $8-12 \mathrm{~min}$ of whole-cell recording ( $2 \pm 10 \%$ increase, $n=6, p=0.97$, paired $t$ test). The use of $\mathrm{C}_{\mathrm{m}}$ recordings confirms results obtained using paired whole-cell measurements of synaptic transmission. $G \beta \gamma$ has been linked to changes in vesicle fusion mode, shifting to a greater proportion of kiss-and-run exo/endocytosis (Chen et al., 2005; Photowala et al., 2006; Schwartz et al., 2007; Yoon et al., 2008), possibly due to interactions of the endocytic protein dynamin with $\mathrm{G} \beta \gamma$ (Lin and Gilman, 1996). These $\mathrm{C}_{\mathrm{m}}$ recordings also allowed us to assess the influence of $\mathrm{G} \beta_{1} \gamma_{1}$ on endocytic vesicle retrieval. Despite the reduction in exocytotic $\mathrm{C}_{\mathrm{m}}$ increases in the presence of $\mathrm{G} \beta_{1} \gamma_{1}$, the kinetics of endocytic membrane retrieval appeared unchanged $\left(t_{(50)}=688 \pm 100 \mathrm{~ms}\right.$ with boiled $\mathrm{G} \beta_{1} \gamma_{1}$ controls and $632 \pm 80 \mathrm{~ms}$ with unboiled $\left.\mathrm{G} \beta_{1} \gamma_{1}, p=0.68\right)$. As noted in Materials and Methods, we included the glutamate transporter inhibitor TBOA in the bath during $\mathrm{C}_{\mathrm{m}}$ recordings to minimize artifacts from activation of the transporter $\mathrm{Cl}^{-}$conductance. At calyx of Held synapses, raising cleft glutamate levels following glutamate transporter inhibition leads to an mGluR-dependent presynaptic inhibition of synaptic release (Renden et al., 2005). In our $\mathrm{C}_{\mathrm{m}}$ recordings, the presynaptic cone was voltage-clamped to inhibit glutamate release and so cleft glutamate was unlikely to be similarly elevated. Consistent with this, a prior study from our laboratory showed that TBOA had no significant effect on cone-driven EPSCs recorded in a paired voltage-clamp recording configuration (Cadetti et al., 2008).

To test that the inhibition in synaptic transmission accompanying dialysis of cones with exogenous $\mathrm{G} \beta_{1} \gamma_{1}$ is the result of G $\beta \gamma$-SNARE interactions, we incubated retinal slices with BoNT/A ( $20 \mathrm{~nm}$ ) for 30 or 60 min before beginning experiments (Fig. 9). For retinal tissue treated for $30 \mathrm{~min}$ with BoNT/A, the EPSC amplitude was reduced to $89 \pm 8 \%$ of the first response by $\sim 10$ min after establishing whole-cell recording configuration with a pipette solution containing $300 \mathrm{nM} \mathrm{G} \beta_{1} \gamma_{1}(n=5$ cone/HC pairs). This is a less dramatic reduction in EPSC amplitude than seen with $300 \mathrm{nM} \mathrm{G} \beta_{1} \gamma_{1}$ in retinas not pretreated with BoNT/A (reduced to $56 \%$ of first EPSC, above). Because longer incubation with BoNT/A will lead to a greater quantity of SNAP-25 lacking the $\mathrm{C}$ terminus, we next doubled the BoNT/A incubation time to $60 \mathrm{~min}$ before beginning recordings. In these slices, the effect of $\mathrm{G} \beta_{1} \gamma_{1}$ on the EPSC was largely reversed, with the EPSC amplitude being $117 \pm 21 \%$ of the first EPSC recorded at break-in $(n=$ 6 cone-HC pairs). This approached the $\sim 131 \%$ increase in EPSC amplitude seen with boiled $\mathrm{G} \beta_{1} \gamma_{1}$, above (Fig. 6). Thus, G $\beta \gamma$ dependent inhibition of exocytosis in cones appears to depend on an intact SNAP-25 C terminus, supporting a role for $\mathrm{G} \beta \gamma$-SNAP25-mediated inhibition of exocytosis following Group III mGluR activation.

\section{Discussion}

Presynaptic mGluRs in retina and throughout the CNS suppress synaptic transmission by several mechanisms including inhibition of voltage-gated $\mathrm{Ca}^{2+}$ channels, enhancement of $\mathrm{K}^{+}$conductances, and direct G-protein interactions with the vesicle fusion machinery (Sladeczek et al., 1993; Scanziani et al., 1995; Takahashi et al., 1996, 2001; von Gersdorff et al., 1997; Cochilla and Alford, 1998; Koulen et al., 1999, 2005; Awatramani and Slaughter, 2001; Higgs and Lukasiewicz, 2002; Higgs et al., 2002; Lorez et al., 2003; Hosoi et al., 2005; Mateo and Porter, 2007; Quraishi et al., 2007; Erdmann et al., 2012). Here, we show that mGluR-dependent suppression of synaptic transmission in cones occurs, in part, due to $\mathrm{G} \beta \gamma$ interacting with the SNAP-25 C terminus. mGluR activation also reduced $\mathrm{I}_{\mathrm{Ca}}$, although this was not mimicked by direct introduction of $\mathrm{G} \beta \gamma$ through the cone patch pipette, implying that it depends on $G \alpha$ pathways. Although HCs also reportedly express mGluRs (Linn and Gafka, 1999), the effects of L-AP4 here were clearly presynaptic in origin, as they were blocked by introduction of the ct-SNAP25 peptide into the cone during paired recordings. The effect of G $\beta \gamma$ on exocytosis was confirmed to be the result of $\mathrm{G} \beta \gamma$ interacting with SNAP- 25 by the inhibition of L-AP4 effects by either pretreatment with BoNT/A or by introduction of the ct-SNAP-25 peptide. More- 
A

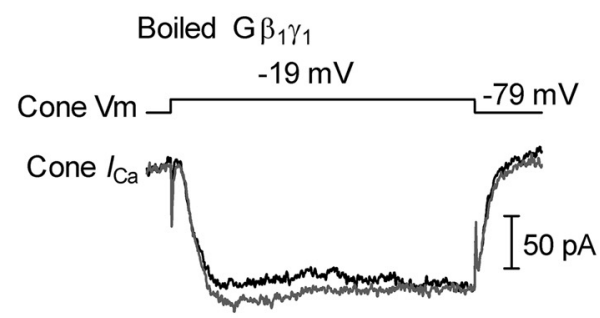

HC EPSC

C
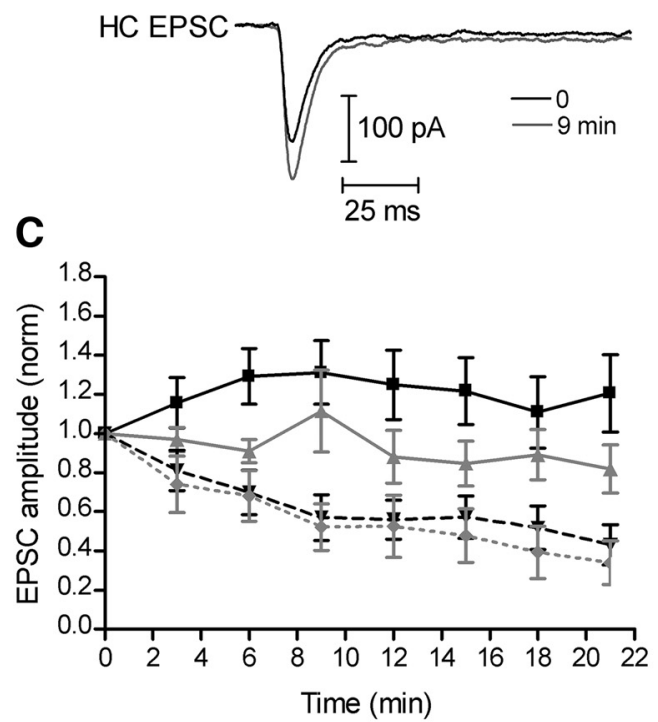

E

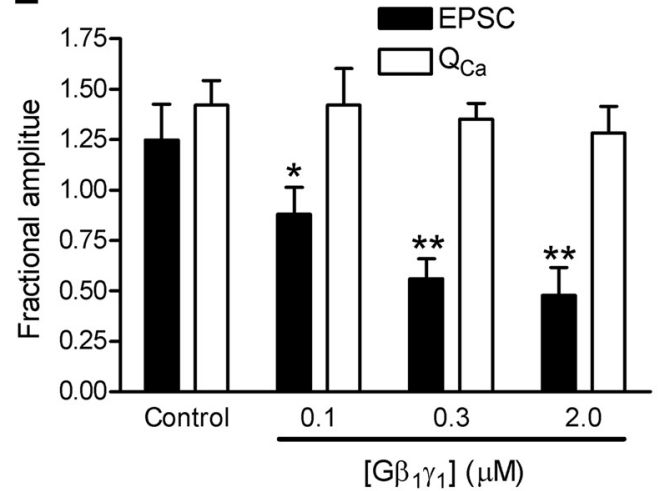

G

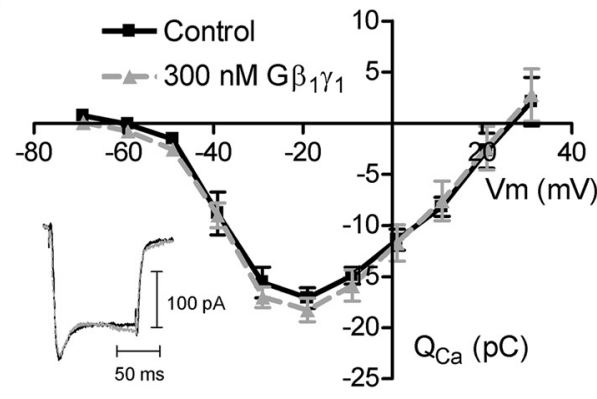

B $300 \mathrm{nMG} \beta_{1} \gamma_{1}$
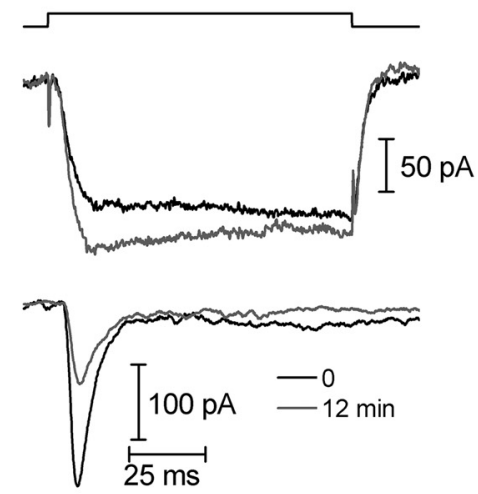

D

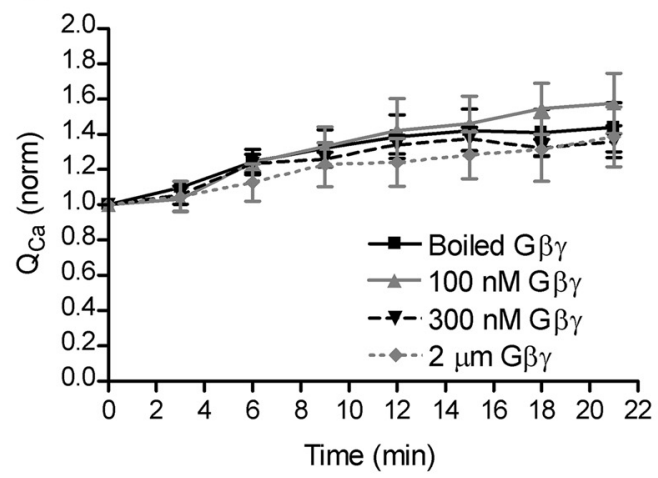

F

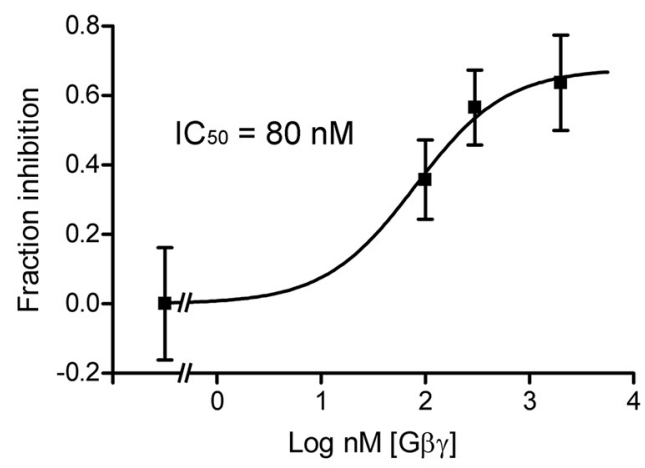

H

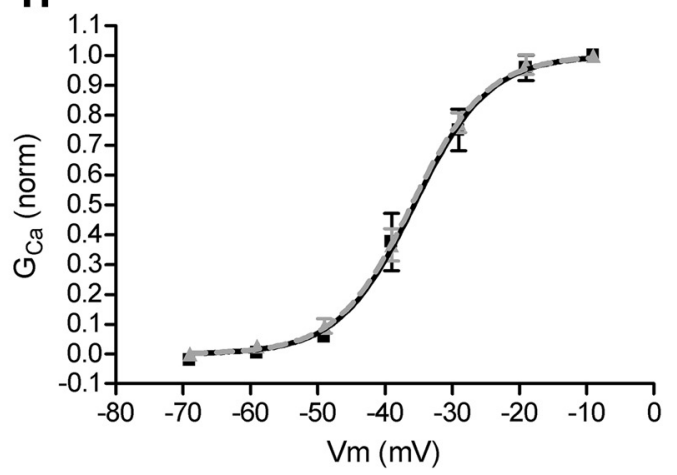

Figure 7. Cone synaptic transmission is inhibited by direct introduction of $\mathrm{G} \beta_{1} \gamma_{1}$ subunits. $A$, Paired cone-HC voltage-clamp recordings in which the cone patch pipette contained boiled $\mathrm{G} \beta_{1} \gamma_{1}$ subunits. The cone was depolarized $\left(-79 \mathrm{to}-19 \mathrm{mV}, 100 \mathrm{~ms}\right.$ ) every $3 \mathrm{~min}$, triggering an $\mathrm{EPSC}$ in the $\mathrm{HC}$. Cone $\mathrm{I}_{\mathrm{Ca}}$ was recorded using a $\mathrm{P} / 8$ leak subtraction protocol. Over the course of the recording, both cone $\mathrm{Ca}^{2+}$ influx and the HC EPSC increased slightly. $\boldsymbol{B}$, Similar experiment in which the cone patch pipette solution contained $300 \mathrm{~nm} \mathrm{G} \beta_{1} \gamma_{1}$. Similar to the boiled control $(\boldsymbol{A})$, $\mathrm{Ca}^{2+}$ influx ran up over the recording. Unlike the boiled control, the EPSC amplitude was inhibited after several minutes of whole-cell recording. $C$, Group EPSC time series showing that EPSC amplitude (mean \pm SEM) gradually ran up over the course of the recording when the cone was dialyzed with boiled $\mathrm{G} \beta_{1} \gamma_{1}$ (solid black, $n=7$ ) but was inhibited when the pipette (Figure legend continues.) 
A

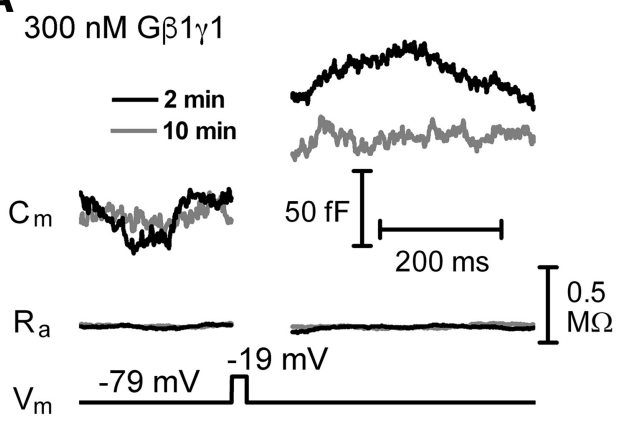

B

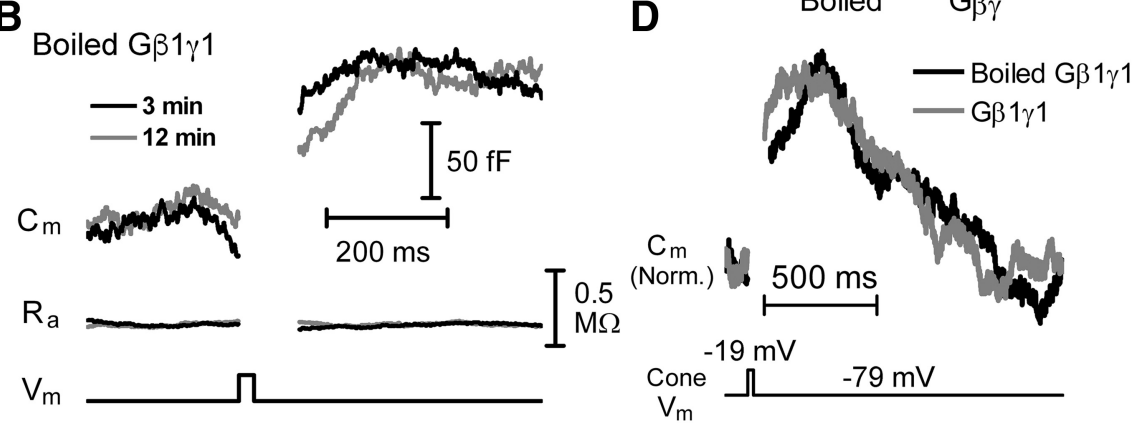

Figure 8. Exocytotic capacitance responses are inhibited by $\mathrm{G} \beta_{1} \gamma_{1}$. A , Whole-cell $C_{m}$ recording of a cone in which the patch pipette contained $300 \mathrm{~nm} \mathrm{G} \beta_{1} \gamma_{1}$. After 10 min of recording (gray trace), the exocytotic $C_{m}$ increase evoked by a depolarizing stimulus ( -79 to $-19 \mathrm{mV}, 25 \mathrm{~ms}$ ) was reduced relative to a response recorded early in the recording (black trace). The access resistance $\left(R_{a}\right)$ was unchanged by the depolarizing stimulus. $B$, A similar experiment to that illustrated in $A$, except that the cone patch pipette contained boiled $\mathrm{G}_{1} \gamma_{1}$. In this recording, the $C_{m}$ response recorded late in the recording ( $12 \mathrm{~min}$, gray trace) was similar to the response recorded early in the recording ( $3 \mathrm{~min}$, black trace). $C$, Group data (mean $\pm S E M$ ) of exocytotic $C_{m}$ responses recorded late (9-12 min of whole-cell recording) normalized to early responses ( $0-3$ min recording) showing that, when cones were dialyzed with functional $\mathrm{G} \beta_{1} \gamma_{1}$ ( $n=6$ cones), the responses were significantly reduced ( ${ }^{* * *} p<0.005$, paired $t$ test), whereas those with the boiled $\mathrm{G} \beta_{1} \gamma_{1}$ were not affected (not significant, $p>0.05$, paired $t$ test). $\boldsymbol{D}$, Normalized whole-cell $C_{m}$ traces in which the patch pipette contained either $300 \mathrm{~nm} G \beta_{1} \gamma_{1}$ or boiled $\mathrm{G} \beta_{1} \gamma_{1}$ displayed on an expanded time base to illustrate that the rapid endocytic decline in $C_{m}$ was unaffected by $G \beta_{1} \gamma_{1}$. Displayed traces are from two different cones, and responses were evoked $\sim 10 \mathrm{~min}$ into whole-cell recording with a $25 \mathrm{~ms}$ depolarizing step (to $-19 \mathrm{mV}$ from $-79 \mathrm{mV}$ ).

over, direct introduction of $\mathrm{G} \beta \gamma$ subunits dose-dependently inhibited exocytosis, and this effect was inhibited by BoNT/A pretreatment. G $\beta \gamma$-SNARE interactions triggered by $\mathrm{G}_{\mathrm{i} / \mathrm{o}}$-coupled GPCRs have been identified in a handful of other synapses: in mammals, the hippocampal CA1-subicular synapse (Hamid et al., 2014), Schaeffer collateral-CA1 synapses (Zhang et al., 2011), and inputs to the amygdala (Delaney et al., 2007), and in lamprey, reticulospinal axon synapses (Takahashi et al., 2001; Gerachshenko et al., 2005).

\section{$\leftarrow$}

(Figure legend continued.) contained functional $\mathrm{G} \beta_{1} \gamma_{1}$ subunits (solid gray, $100 \mathrm{~nm}, n=4$; dashed black, $300 \mathrm{~nm}, n=8$; dashed gray, $2 \mu \mathrm{m}, n=5$ ). $\boldsymbol{D}$, Time series measurements of integrated $\mathrm{I}_{\mathrm{Ca}}\left(\mathrm{Q}_{\mathrm{Ca}_{2}}\right.$ mean $\left.\pm \mathrm{SEM}\right)$ showing that $\mathrm{Ca}^{2+}$ influx was similar over the course of the recording whether the cone pipette contained boiled or functional $G \beta_{1} \gamma_{1}$ subunits. $\boldsymbol{E}$, Group data (mean + SEM) showing the EPSC and $Q_{C_{a}}$ measured at 15 min of recording relative to the first response (at time $=0$ ). The EPSC amplitude was significantly reduced $\left({ }^{*} p<0.05,{ }^{* *} p<\right.$ 0.01 , unpaired $t$ tests) relative to the boiled control, but $Q_{C a}$ was not affected ( $p>0.05$, unpaired $t$ test). $F$, Dose-response plot of data normalized for runup in the boiled condition and fit with a sigmoidal dose-response curve showing that $\mathrm{G} \beta_{1} \gamma_{1}$ effects on EPSCs had an $\mathrm{IC}_{50}$ of 80 nм. $\mathbf{G}$, Cone $\mathrm{Ca}^{2+}$ influx (mean $\pm \mathrm{SEM}$ ) recorded at a series of test potentials using a P/8 leak subtraction protocol (100 ms steps) showing that the current amplitude was similar in both $\mathrm{G} \beta_{1} \gamma_{1}$ boiled controls (solid black line, $n=5$ cones) and when cones were dialyzed with 300 nм $G \beta_{1} \gamma_{1}$ (dashed gray line, $n=6$ cones). $\boldsymbol{H}$, Plot of normalized $\mathrm{Ca}^{2+}$ conductance $\left(G_{\mathrm{Ca}^{\prime}}\right.$ mean $\pm \mathrm{SEM}$ ) at a series of test potentials and fit with Boltzmann functions showing that the $\mathrm{I}_{\mathrm{Ca}}$ voltage dependence was similar when cones were dialyzed with either $\mathrm{G} \beta_{1} \gamma_{1}$ or boiled $\mathrm{G} \beta_{1} \gamma_{1}$. The $G \beta_{1} \gamma_{1} V_{50}$ was $-35.8 \pm 1.3 \mathrm{mV}$, and the boiled control $V_{50}$ was $-35.3 \pm 2.0 \mathrm{mV}(p>$ 0.05 , unpaired $t$ test).
Ours is the first study demonstrating the existence of G $\beta \gamma$-SNAP-25 interactiondependent modulation of synaptic transmission in the retina and at a ribbon-type synapse.

$\mathrm{G} \beta \gamma$ regulates synaptic transmission by several mechanisms. Among these, direct interactions of $\mathrm{G} \beta \gamma$ with the poreforming $\alpha 1$ subunit of $\mathrm{N}$ - and P/Q-type $\mathrm{Ca}^{2+}$ channels have been shown to reduce synaptic transmission via a voltagedependent mechanism for inhibition of $\mathrm{I}_{\mathrm{Ca}}$ (Bean, 1989; Tedford and Zamponi, 2006; Currie, 2010). A comparable inhibition does not seem to occur at CaV1.4 ( $\alpha 1 \mathrm{f})$ L-type channels that regulate synaptic release from photoreceptors due to the absence of a key G $\beta \gamma$-interacting sequence in the $\alpha 1$ subunits (Herlitze et al., 1997; Furukawa et al., 1998a, b; Currie, 2010). However, a handful of studies have revealed a that $G \beta \gamma$ is capable of distinct voltage-independent direct inhibition of CaV1.2 ( $\alpha 1 \mathrm{C})$ L-type channels in vitro (Ivanina et al., 2000) and endogenous L-type channels in retinal ganglion cells (Farrell et al., 2014). In our study, although mGluR activation reduced $\mathrm{Ca}^{2+}$ influx (notable after correction for runup), two results indicate that this occurred independently of $\mathrm{G} \beta \gamma$. First, although the ctSNAP-25 peptide prevented a portion of the mGluR-dependent inhibition, it had no effect on $\mathrm{I}_{\mathrm{Ca}}$ effects. Second, direct introduction of $\mathrm{G} \beta \gamma$ subunits into cones had no effect on $\mathrm{I}_{\mathrm{Ca}}$ amplitude or voltage dependence.

$\mathrm{G} \beta \gamma$ can also indirectly regulate synaptic transmission by gating G-protein activated inwardly rectifying $\mathrm{K}^{+}$channels expressed somatically or at presynaptic active zones (Ladera et al., 2008; Fernández-Alacid et al., 2009; Michaeli and Yaka, 2010; Betke et al., 2012). This increases $\mathrm{K}^{+}$conductance, providing a voltage shunt and hyperpolarizing the neuron. Although G-protein activated inwardly rectifying $\mathrm{K}^{+}$channels might influence the cone voltage responses, we voltage-clamped cones and used $\mathrm{Cs}^{+}$-based pipette solutions and therefore did not test for such a contribution.

Thus, our results do not support $\mathrm{G} \beta \gamma$-dependent regulation of $\mathrm{I}_{\mathrm{Ca}}$ or $\mathrm{I}_{\mathrm{K}}$ underlying the effects on exocytosis, although they are consistent with a small contribution from $\mathrm{G} \alpha$-dependent $\mathrm{I}_{\mathrm{Ca}}$ effects. Instead, our major finding is that $\mathrm{mGluR}$ activation reduces cone synaptic transmission via direct G $\beta \gamma$ interactions with SNAP-25, a core SNARE protein required for $\mathrm{Ca}^{2+}$-triggered exocytosis (Banerjee et al., 1996; Bronk et al., 2007). G $\beta \gamma /$ SNARE interactions have been extensively characterized in lamprey reticulospinal-motor neuron synapses and also demonstrated to regulate exocytosis in hippocampus, amygdala, and pancreatic $\beta$ cells (Chen et al., 2005; Photowala et al., 2006; Schwartz et al., 2007; Yoon et al., 2008). Other work has shown that mGluRs inhibit synaptic inputs onto hippocampal granule cells downstream of $\mathrm{Ca}^{2+}$ entry and independently of stereotypical GPCR/G $\alpha$ dependent pathway blockers (Erdmann et al., 2012), a result likely attributable to $\mathrm{G} \beta \gamma$-SNARE interactions.

By interacting with the SNAP-25 C terminus, G $\beta \gamma$ competes with binding of $\mathrm{Ca}^{2+}$-bound synaptotagmin1 (syt1) (Gerachshenko 
et al., 2005; Yoon et al., 2007; Wells et al., 2012; Zurawski et al., 2016). G $\beta \gamma$ also interacts with the SNAP-25 N terminus (Wells et al., 2012), although the major influence on exocytosis is due to C-terminal interactions. The selective influence of $\mathrm{G} \beta \gamma$ on $\mathrm{Ca}^{2+}$ dependent exocytosis is a likely explanation for why L-AP4 reduces HC mEPSCs, which are the result of both $\mathrm{Ca}^{2+}$-dependent and $\mathrm{Ca}^{2+}$-independent exocytosis, without any apparent effect on cone quantal glutamate transporter currents, which are entirely due to $\mathrm{Ca}^{2+}$-independent exocytosis in cones (Maple et al., 1994; Cork et al., 2016). While syt $1 / 2$ are the major exocytotic $\mathrm{Ca}^{2+}$ sensors in most neurons, it is unclear which synaptotagmin isoform is responsible for photoreceptor exocytosis (Berntson and Morgans, 2003; Heidelberger et al., 2003; Kreft et al., 2003; Fox and Sanes, 2007). Different isoforms might result in subtly different G $\beta \gamma$-SNAP-25-mediated effects on exocytosis. Binding studies also indicate that $\mathrm{G} \beta \gamma$ interacts with syntaxin $1 \mathrm{a}$ where it also competes with $\mathrm{Ca}^{2+}$-dependent synaptotagmin interactions (Yoon et al., 2007). This interaction occurs at the syntaxin $1 \mathrm{a} \mathrm{H} 3$ domain, a region important for interaction with synaptobrevin and SNAP-25 (Hayashi et al., 1994; McMahon and Südhof, 1995; Ramakrishnan et al., 2009). Of note, retinal ribbon synapses, such as those found in cones, contain synataxin3 rather than syntaxin1a (Brandstätter et al., 1996; Morgans et al., 1996), which shares a 61\% homology with syntaxin1a (Bennett et al., 1993).

It is unclear exactly how G $\beta \gamma / \mathrm{SNARE}$ interactions change the nature of exocytosis. The competition of $\mathrm{G} \beta \gamma$ with $\mathrm{Ca}^{2+}$-synaptotagmin binding to SNARE proteins points toward a reduced $\mathrm{Ca}^{2+}$ sensitivity of release (Gerachshenko et al., 2005; Delaney et al., 2007; Yoon et al., 2007; Erdmann et al., 2012). G $\beta \gamma$ interactions also change the vesicle fusion mode so that release shifts to being dominated by kiss-and-run rather full-collapse fusion (Chen et al., 2005; Photowala et al., 2006; Schwartz et al., 2007; Yoon et al., 2008), possibly via interactions with the endocytic protein dynamin (Lin and Gilman, 1996). In kiss-andrun, transmitter is released through a narrow fusion pore formed at the mouth of the synaptic vesicle, reducing the amount of exocytosed transmitter and slowing mEPSC kinetics (He et al., 2006; He and $\mathrm{Wu}, 2007)$. In our recordings of postsynaptic mEPSCs in HCs, however, neither the mEPSC kinetics nor amplitude were altered by L-AP4 application, and the time course of endocytic membrane retrieval measured with $C_{m}$ recordings was unaffected by $G \beta \gamma$ subunits, pointing instead to a change in effective vesicle pool size or release probability. The lack of an effect on fusion mode might reflect the minimal reliance of cone endocytosis on dynamin (Van Hook and Thoreson, 2012).

What functional role(s) do G $\beta \gamma /$ SNARE interactions play in cones? 5-HT leads to $\mathrm{G} \beta \gamma$-dependent synaptic depression on a very rapid time scale $(\sim 20 \mathrm{~ms})$ at the lamprey reticulospinal synapse (Gerachshenko et al., 2005). mGluRs can function as autoreceptors that rapidly influence synaptic transmission, making them contributors to short-term synaptic plasticity (von Gersdorff et al., 1997; Awatramani and Slaughter, 2001; Chen et al., 2002; Lorez et al., 2003; Mateo and Porter, 2007; Kyuyoung and Huguenard, 2014). Rapid synaptic depression is key for shaping the frequency response and filtering properties of synaptic transmission, and this can be influenced by several factors at the photoreceptor synapse (DeVries, 2000; Armstrong-Gold and Rieke, 2003; Zhang and Wu, 2005; DeVries et al., 2006; Van Hook et al., 2014). Indeed, blockade of mGluRs using CPPG reduced the amplitude of $\mathrm{HC}$ responses to a 2 $\mathrm{Hz}$ light stimulus. One interpretation of these data is that inhibition of presynaptic mGluRs leads to synaptic vesicle pool depletion by removing a mGluR-mediated "brake" on exocytosis, consistent with the increase in mEPSC frequency, as has been proposed previously 
(Hosoi et al., 2005). Increased cleft glutamate concentration with CPPG might also reduce synaptic responses via AMPAR desensitization and saturation. However, we did not see any change in mEPSC amplitude with CPPG application, arguing against a substantial effect of desensitization/saturation. G $\beta \gamma$-dependent synaptic inhibition of release might also support adaptation at local spatial scales, with glutamate spillover to neighboring cones potentially influencing color opponent and center-surround receptive fields via mGluR (Luo and Liang, 2003; Szmajda and Devries, 2011).

Photoreceptors contain a variety of GPCRs beyond mGluRs, such as dopamine, adenosine, somatostatin, and endocannabinoid receptors that might inhibit photoreceptor synaptic transmission via G $\beta \gamma$-SNARE interactions. Finally, phototransduction itself is a GPCR-dependent process, and phototransduction proteins translocate from outer segments and regulate synaptic transmission (Sokolov et al., 2004; Yamamoto et al., 2007; Herrmann et al., 2010; Huang et al., 2010; Majumder et al., 2013). It is a tantalizing possibility that $\mathrm{G} \beta \gamma$ translocating from outer segments might contribute to synaptic light adaptation by interacting with SNARE proteins at the terminal.

\section{References}

Akopian A, Witkovsky P (1996) D2 dopamine receptor-mediated inhibition of a hyperpolarization-activated current in rod photoreceptors. J Neurophysiol 76:1828-1835. Medline

Akopian A, Johnson J, Gabriel R, Brecha N, Witkovsky P (2000) Somatostatin modulates voltage-gated $\mathrm{K}(+)$ and $\mathrm{Ca}(2+)$ currents in rod and cone photoreceptors of the salamander retina. J Neurosci 20:929-936. Medline

Arkin MS, Miller RF (1987) Subtle actions of 2-amino-4-phosphonobutyrate (APB) on the Off pathway in the mudpuppy retina. Brain Res 426:142-148. CrossRef Medline

Armstrong-Gold CE, Rieke F (2003) Bandpass filtering at the rod to secondorder cell synapse in salamander (Ambystoma tigrinum) retina. J Neurosci 23:3796-3806. Medline

Awatramani GB, Slaughter MM (2001) Intensity-dependent, rapid activation of presynaptic metabotropic glutamate receptors at a central synapse. J Neurosci 21:741-749. Medline

Banerjee A, Kowalchyk JA, DasGupta BR, Martin TF (1996) SNAP-25 is required for a late postdocking step in $\mathrm{Ca}^{2+}$-dependent exocytosis. J Biol Chem 271:20227-20230. CrossRef Medline

Bartoletti TM, Thoreson WB (2011) Quantal amplitude at the cone ribbon synapse can be adjusted by changes in cytosolic glutamate. Mol Vis 17: 920-931. Medline

Bartoletti TM, Babai N, Thoreson WB (2010) Vesicle pool size at the salamander cone ribbon synapse. J Neurophysiol 103:419-423. CrossRef Medline

Bartoletti TM, Jackman SL, Babai N, Mercer AJ, Kramer RH, Thoreson WB (2011) Release from the cone ribbon synapse under bright light conditions can be controlled by the opening of only a few $\mathrm{Ca}(2+)$ channels. J Neurophysiol 106:2922-2935. CrossRef Medline

Bean BP (1989) Neurotransmitter inhibition of neuronal calcium currents by changes in channel voltage dependence. Nature 340:153-156. CrossRef Medline

Bennett MK, García-Arrarás JE, Elferink LA, Peterson K, Fleming AM, Hazuka CD, Scheller RH (1993) The syntaxin family of vesicular transport receptors. Cell 74:863-873. CrossRef Medline

Berntson AK, Morgans CW (2003) Distribution of the presynaptic calcium sensors, synaptotagmin I/II and synaptotagmin III, in the goldfish and rodent retinas. J Vis 3:274-280. CrossRef Medline

Betke KM, Wells CA, Hamm HE (2012) GPCR mediated regulation of synaptic transmission. Prog Neurobiol 96:304-321. CrossRef Medline

Blackmer T, Larsen EC, Takahashi M, Martin TF, Alford S, Hamm HE (2001) G protein betagamma subunit-mediated presynaptic inhibition: regulation of exocytotic fusion downstream of $\mathrm{Ca}^{2+}$ entry. Science 292: 293-297. CrossRef Medline

Blackmer T, Larsen EC, Bartleson C, Kowalchyk JA, Yoon EJ, Preininger AM, Alford S, Hamm HE, Martin TF (2005) G protein betagamma directly regulates SNARE protein fusion machinery for secretory granule exocytosis. Nat Neurosci 8:421-425. CrossRef Medline
Brandstätter JH, Wässle H, Betz H, Morgans CW (1996) The plasma membrane protein SNAP-25, but not syntaxin, is present at photoreceptor and bipolar cell synapses in the rat retina. Eur J Neurosci 8:823-828. CrossRef Medline

Bronk P, Deák F, Wilson MC, Liu X, Südhof TC, Kavalali ET (2007) Differential effects of SNAP-25 deletion on $\mathrm{Ca}^{2+}$-dependent and $\mathrm{Ca}^{2+}$ independent neurotransmission. J Neurophysiol 98:794-806. CrossRef Medline

Cadetti L, Bartoletti TM, Thoreson WB (2008) Quantal mEPSCs and residual glutamate: how horizontal cell responses are shaped at the photoreceptor ribbon synapse. Eur J Neurosci 27:2575-2586. CrossRef Medline

Catsicas S, Catsicas M, Keyser KT, Karten HJ, Wilson MC, Milner RJ (1992) Differential expression of the presynaptic protein SNAP-25 in mammalian retina. J Neurosci Res 33:1-9. CrossRef Medline

Chen CY, Ling Eh EH, Horowitz JM, Bonham AC (2002) Synaptic transmission in nucleus tractus solitarius is depressed by Group II and III but not Group I presynaptic metabotropic glutamate receptors in rats. J Physiol 538:773-786. CrossRef Medline

Chen XK, Wang LC, Zhou Y, Cai Q, Prakriya M, Duan KL, Sheng ZH, Lingle C, Zhou Z (2005) Activation of GPCRs modulates quantal size in chromaffin cells through G(betagamma) and PKC. Nat Neurosci 8:11601168. CrossRef Medline

Cochilla AJ, Alford S (1998) Metabotropic glutamate receptor-mediated control of neurotransmitter release. Neuron 20:1007-1016. CrossRef Medline

Corey DP, Dubinsky JM, Schwartz EA (1984) The calcium current in inner segments of rods from the salamander (Ambystoma tigrinum) retina. J Physiol 354:557-575. CrossRef Medline

Cork KM, Van Hook MJ, Thoreson WB (2016) Mechanisms, pools, and sites of spontaneous vesicle release at synapses of rod and cone photoreceptors. Eur J Neurosci 44:2015-2027. CrossRef Medline

Currie KP (2010) G protein modulation of $\mathrm{CaV} 2$ voltage-gated calcium channels. Channels (Austin) 4:497-509. CrossRef Medline

Delaney AJ, Crane JW, Sah P (2007) Noradrenaline modulates transmission at a central synapse by a presynaptic mechanism. Neuron $56: 880-892$. CrossRef Medline

DeVries SH (2000) Bipolar cells use kainate and AMPA receptors to filter visual information into separate channels. Neuron 28:847-856. CrossRef Medline

DeVries SH, Li W, Saszik S (2006) Parallel processing in two transmitter microenvironments at the cone photoreceptor synapse. Neuron 50:735748. CrossRef Medline

Duncan G, Rabl K, Gemp I, Heidelberger R, Thoreson WB (2010) Quantitative analysis of synaptic release at the photoreceptor synapse. Biophys J 98:2102-2110. CrossRef Medline

Eggermann E, Bucurenciu I, Goswami SP, Jonas P (2011) Nanodomain coupling between $\mathrm{Ca}^{2+}$ channels and sensors of exocytosis at fast mammalian synapses. Nat Rev Neurosci 13:7-21. CrossRef Medline

Erdmann E, Rupprecht V, Matthews E, Kukley M, Schoch S, Dietrich D (2012) Depression of release by mGluR8 alters $\mathrm{Ca}^{2+}$ dependence of release machinery. Cereb Cortex 1991 22:1498-1509. CrossRef Medline

Fan SF, Yazulla S (2004) Inhibitory interaction of cannabinoid CB1 receptor and dopamine $\mathrm{D} 2$ receptor agonists on voltage-gated currents of goldfish cones. Vis Neurosci 21:69-77. CrossRef Medline

Farrell SR, Rankin DR, Brecha NC, Barnes S (2014) Somatostatin receptor subtype 4 modulates L-type calcium channels via G $\beta \gamma$ and PKC signaling in rat retinal ganglion cells. Channels (Austin) 8:519-527. CrossRef Medline

Fernández-Alacid L, Aguado C, Ciruela F, Martín R, Colón J, Cabañero MJ, Gassmann M, Watanabe M, Shigemoto R, Wickman K, Bettler B, Sánchez-Prieto J, Luján R (2009) Subcellular compartment-specific molecular diversity of presynaptic and postsynaptic GABA-activated GIRK channels in Purkinje cells. J Neurochem 110:1363-1376. CrossRef Medline

Fox MA, Sanes JR (2007) Synaptotagmin I and II are present in distinct subsets of central synapses. J Comp Neurol 503:280-296. CrossRef Medline

Furukawa T, Miura R, Mori Y, Strobeck M, Suzuki K, Ogihara Y, Asano T, Morishita R, Hashii M, Higashida H, Yoshii M, Nukada T (1998a) Differential interactions of the $\mathrm{C}$ terminus and the cytoplasmic I-II loop of neuronal $\mathrm{Ca}^{2+}$ channels with G-protein alpha and beta gamma subunits: II. Evidence for direct binding. J Biol Chem 273:17595-17603. CrossRef Medline 
Furukawa T, Nukada T, Mori Y, Wakamori M, Fujita Y, Ishida H, Fukuda K, Kato S, Yoshii M (1998b) Differential interactions of the C terminus and the cytoplasmic I-II loop of neuronal $\mathrm{Ca}^{2+}$ channels with G-protein alpha and beta gamma subunits: I. Molecular determination. J Biol Chem 273: 17585-17594. CrossRef Medline

Gerachshenko T, Blackmer T, Yoon EJ, Bartleson C, Hamm HE, Alford S (2005) Gbetagamma acts at the C terminus of SNAP-25 to mediate presynaptic inhibition. Nat Neurosci 8:597-605. CrossRef Medline

Gerona RR, Larsen EC, Kowalchyk JA, Martin TF (2000) The C terminus of SNAP25 is essential for $\mathrm{Ca}(2+)$-dependent binding of synaptotagmin to SNARE complexes. J Biol Chem 275:6328-6336. CrossRef Medline

Gottschall PE, Ajmo JM, Eakin AK, Howell MD, Mehta H, Bailey LA (2010) Panel of synaptic protein ELISAs for evaluating neurological phenotype. Exp Brain Res 201:885-893. CrossRef Medline

Goutman JD, Glowatzki E (2007) Time course and calcium dependence of transmitter release at a single ribbon synapse. Proc Natl Acad Sci U S A 104:16341-16346. CrossRef Medline

Grabner CP, Gandini MA, Rehak R, Le Y, Zamponi GW, Schmitz F (2015) RIM1/2-mediated facilitation of Cav1.4 channel opening is required for $\mathrm{Ca}^{2+}$-stimulated release in mouse rod photoreceptors. J Neurosci 35: 13133-13147. CrossRef Medline

Grabs D, Bergmann M, Urban M, Post A, Gratzl M (1996) Rab3 proteins and SNAP-25, essential components of the exocytosis machinery in conventional synapses, are absent from ribbon synapses of the mouse retina. Eur J Neurosci 8:162-168. CrossRef Medline

Greenlee MH, Roosevelt CB, Sakaguchi DS (2001) Differential localization of SNARE complex proteins SNAP-25, syntaxin, and VAMP during development of the mammalian retina. J Comp Neurol 430:306-320. CrossRef Medline

Hamid E, Church E, Wells CA, Zurawski Z, Hamm HE, Alford S (2014) Modulation of neurotransmission by GPCRs is dependent upon the microarchitecture of the primed vesicle complex. J Neurosci 34:260-274. CrossRef Medline

Hayashi T, McMahon H, Yamasaki S, Binz T, Hata Y, Südhof TC, Niemann H (1994) Synaptic vesicle membrane fusion complex: action of clostridial neurotoxins on assembly. EMBO J 13:5051-5061. Medline

He L, Wu LG (2007) The debate on the kiss-and-run fusion at synapses. Trends Neurosci 30:447-455. CrossRef Medline

He L, Wu XS, Mohan R, Wu LG (2006) Two modes of fusion pore opening revealed by cell-attached recordings at a synapse. Nature 444:102-105. CrossRef Medline

Heidelberger R, Wang MM, Sherry DM (2003) Differential distribution of synaptotagmin immunoreactivity among synapses in the goldfish, salamander, and mouse retina. Vis Neurosci 20:37-49. CrossRef Medline

Heidelberger R, Thoreson WB, Witkovsky P (2005) Synaptic transmission at retinal ribbon synapses. Prog Retin Eye Res 24:682-720. CrossRef Medline

Herlitze S, Hockerman GH, Scheuer T, Catterall WA (1997) Molecular determinants of inactivation and $\mathrm{G}$ protein modulation in the intracellular loop connecting domains I and II of the calcium channel alphalA subunit. Proc Natl Acad Sci U S A 94:1512-1516. CrossRef Medline

Herrmann R, Lobanova ES, Hammond T, Kessler C, Burns ME, Frishman LJ, Arshavsky VY (2010) Phosducin regulates transmission at the photoreceptor-to-ON-bipolar cell synapse. J Neurosci 30:3239-3253. CrossRef Medline

Higgs MH, Lukasiewicz PD (2002) Activation of group II metabotropic glutamate receptors inhibits glutamate release from salamander retinal photoreceptors. Vis Neurosci 19:275-281. CrossRef Medline

Higgs MH, Romano C, Lukasiewicz PD (2002) Presynaptic effects of group III metabotropic glutamate receptors on excitatory synaptic transmission in the retina. Neuroscience 115:163-172. CrossRef Medline

Hirano AA, Brandstätter JH, Morgans CW, Brecha NC (2011) SNAP25 expression in mammalian retinal horizontal cells. J Comp Neurol 519:972988. CrossRef Medline

Hirasawa H, Shiells R, Yamada M (2002) A metabotropic glutamate receptor regulates transmitter release from cone presynaptic terminals in carp retinal slices. J Gen Physiol 119:55-68. CrossRef Medline

Honer WG, Hu L, Davies P (1993) Human synaptic proteins with a heterogeneous distribution in cerebellum and visual cortex. Brain Res 609:920. CrossRef Medline

Hosoi N, Arai I, Tachibana M (2005) Group III metabotropic glutamate receptors and exocytosed protons inhibit L-type calcium currents in cones but not in rods. J Neurosci 25:4062-4072. CrossRef Medline

Huang SP, Brown BM, Craft CM (2010) Visual Arrestin 1 acts as a modulator for $\mathrm{N}$-ethylmaleimide-sensitive factor in the photoreceptor synapse. J Neurosci 30:9381-9391. CrossRef Medline

Humeau Y, Doussau F, Grant NJ, Poulain B (2000) How botulinum and tetanus neurotoxins block neurotransmitter release. Biochimie 82:427446. CrossRef Medline

Ivanina T, Blumenstein Y, Shistik E, Barzilai R, Dascal N (2000) Modulation of L-type $\mathrm{Ca}^{2+}$ channels by gbeta gamma and calmodulin via interactions with N and C termini of alpha 1C. J Biol Chem 275:39846-39854. CrossRef Medline

Jackman SL, Choi SY, Thoreson WB, Rabl K, Bartoletti TM, Kramer RH (2009) Role of the synaptic ribbon in transmitting the cone light response. Nat Neurosci 12:303-310. CrossRef

Koulen P, Kuhn R, Wässle H, Brandstätter JH (1999) Modulation of the intracellular calcium concentration in photoreceptor terminals by a presynaptic metabotropic glutamate receptor. Proc Natl Acad Sci U S A 96: 9909-9914. CrossRef Medline

Koulen P, Liu J, Nixon E, Madry C (2005) Interaction between mGluR8 and calcium channels in photoreceptors is sensitive to pertussis toxin and occurs via $G$ protein betagamma subunit signaling. Invest Ophthalmol Vis Sci 46:287-291. CrossRef Medline

Kreft M, Krizaj D, Grilc S, Zorec R (2003) Properties of exocytotic response in vertebrate photoreceptors. J Neurophysiol 90:218-225. CrossRef Medline

Kyuyoung CL, Huguenard JR (2014) Modulation of short-term plasticity in the corticothalamic circuit by group III metabotropic glutamate receptors. J Neurosci 34:675-687. CrossRef Medline

Ladera C, del Carmen Godino M, José Cabañero M, Torres M, Watanabe M, Luján R, Sánchez-Prieto J (2008) Pre-synaptic GABA receptors inhibit glutamate release through GIRK channels in rat cerebral cortex. J Neurochem 107:1506-1517. CrossRef Medline

Lin HC, Gilman AG (1996) Regulation of dynamin I GTPase activity by G protein betagamma subunits and phosphatidylinositol 4,5-bisphosphate. J Biol Chem 271:27979-27982. CrossRef Medline

Linn CL, Gafka AC (1999) Activation of metabotropic glutamate receptors modulates the voltage-gated sustained calcium current in a teleost horizontal cell. J Neurophysiol 81:425-434. Medline

Logothetis DE, Kurachi Y, Galper J, Neer EJ, Clapham DE (1987) The beta gamma subunits of GTP-binding proteins activate the muscarinic $\mathrm{K}^{+}$ channel in heart. Nature 325:321-326. CrossRef Medline

Lorez M, Humbel U, Pflimlin MC, Kew JN (2003) Group III metabotropic glutamate receptors as autoreceptors in the cerebellar cortex. Br J Pharmacol 138:614-625. CrossRef Medline

Luo FJ, Liang PJ (2003) Metabotropic glutamate receptor-mediated heterosynaptic interaction of red- and green-cone inputs to LHC of carp retina. Brain Res Bull 60:67-71. CrossRef Medline

Majumder A, Pahlberg J, Boyd KK, Kerov V, Kolandaivelu S, Ramamurthy V, Sampath AP, Artemyev NO (2013) Transducin translocation contributes to rod survival and enhances synaptic transmission from rods to rod bipolar cells. Proc Natl Acad Sci U S A 110:12468-12473. CrossRef Medline

Maple BR, Werblin FS, Wu SM (1994) Miniature excitatory postsynaptic currents in bipolar cells of the tiger salamander retina. Vision Res 34: 2357-2362. CrossRef Medline

Mateo Z, Porter JT (2007) Group II metabotropic glutamate receptors inhibit glutamate release at thalamocortical synapses in the developing somatosensory cortex. Neuroscience 146:1062-1072. CrossRef Medline

Mazelova J, Ransom N, Astuto-Gribble L, Wilson MC, Deretic D (2009) Syntaxin 3 and SNAP- 25 pairing, regulated by omega-3 docosahexaenoic acid, controls the delivery of rhodopsin for the biogenesis of cilia-derived sensory organelles, the rod outer segments. J Cell Sci 122:2003-2013. CrossRef Medline

Mazzoni MR, Malinski JA, Hamm HE (1991) Structural analysis of rod GTP-binding protein, Gt: limited proteolytic digestion pattern of Gt with four proteases defines monoclonal antibody epitope. J Biol Chem 266: 14072-14081. Medline

McMahon HT, Südhof TC (1995) Synaptic core complex of synaptobrevin, syntaxin, and SNAP25 forms high affinity alpha-SNAP binding site. J Biol Chem 270:2213-2217. CrossRef Medline

Mercer AJ, Rabl K, Riccardi GE, Brecha NC, Stella SL Jr, Thoreson WB (2011) Location of release sites and calcium-activated chloride channels 
relative to calcium channels at the photoreceptor ribbon synapse. J Neurophysiol 105:321-335. CrossRef Medline

Michaeli A, Yaka R (2010) Dopamine inhibits GABA(A) currents in ventral tegmental area dopamine neurons via activation of presynaptic G-protein coupled inwardly rectifying potassium channels. Neuroscience 165: 1159-1169. CrossRef Medline

Morgans C, Brandstätter JH (2000) SNAP-25 is present on the Golgi apparatus of retinal neurons. Neuroreport 11:85-88. CrossRef Medline

Morgans CW (2001) Localization of the alpha(1F) calcium channel subunit in the rat retina. Invest Ophthalmol Vis Sci 42:2414-2418. Medline

Morgans CW, Brandstätter JH, Kellerman J, Betz H, Wässle H (1996) A SNARE complex containing syntaxin 3 is present in ribbon synapses of the retina. J Neurosci 16:6713-6721. Medline

Nawy S, Sie A, Copenhagen DR (1989) The glutamate analog 2-amino-4phosphonobutyrate antagonizes synaptic transmission from cones to horizontal cells in the goldfish retina. Proc Natl Acad Sci U S A 86:17261730. CrossRef Medline

Otto H, Hanson PI, Chapman ER, Blasi J, Jahn R (1995) Poisoning by botulinum neurotoxin A does not inhibit formation or disassembly of the synaptosomal fusion complex. Biochem Biophys Res Commun 212:945952. CrossRef Medline

Photowala H, Blackmer T, Schwartz E, Hamm HE, Alford S (2006) G protein betagamma-subunits activated by serotonin mediate presynaptic inhibition by regulating vesicle fusion properties. Proc Natl Acad Sci U S A 103:4281-4286. CrossRef Medline

Picaud SA, Larsson HP, Grant GB, Lecar H, Werblin FS (1995a) Glutamategated chloride channel with glutamate-transporter-like properties in cone photoreceptors of the tiger salamander. J Neurophysiol 74:17601771. Medline

Picaud S, Larsson HP, Wellis DP, Lecar H, Werblin F (1995b) Cone photoreceptors respond to their own glutamate release in the tiger salamander. Proc Natl Acad Sci U S A 92:9417-9421. CrossRef Medline

Quraishi S, Gayet J, Morgans CW, Duvoisin RM (2007) Distribution of group-III metabotropic glutamate receptors in the retina. J Comp Neurol 501:931-943. CrossRef Medline

Ramakrishnan NA, Drescher MJ, Drescher DG (2009) Direct interaction of otoferlin with syntaxin 1A, SNAP-25, and the L-type voltage-gated calcium channel Cav1.3. J Biol Chem 284:1364-1372. CrossRef Medline

Reim K, Wegmeyer H, Brandstätter JH, Xue M, Rosenmund C, Dresbach T, Hofmann K, Brose N (2005) Structurally and functionally unique complexins at retinal ribbon synapses. J Cell Biol 169:669-680. CrossRef Medline

Renden R, Taschenberger H, Puente N, Rusakov DA, Duvoisin R, Wang LY, Lehre KP, von Gersdorff H (2005) Glutamate transporter studies reveal the pruning of metabotropic glutamate receptors and absence of AMPA receptor desensitization at mature calyx of Held synapses. J Neurosci 25:8482-8497. CrossRef Medline

Rieke F, Schwartz EA (1996) Asynchronous transmitter release: control of exocytosis and endocytosis at the salamander rod synapse. J Physiol 493: 1-8. CrossRef Medline

Scanziani M, Gahwiler BH, Thompson SM (1995) Presynaptic inhibition of excitatory synaptic transmission by muscarinic and metabotropic glutamate receptor activation in the hippocampus: are $\mathrm{Ca}^{2+}$ channels involved? Neuropharmacology 34:1549-1557. CrossRef Medline

Schiavo G, Santucci A, Dasgupta BR, Mehta PP, Jontes J, Benfenati F, Wilson MC, Montecucco C (1993) Botulinum neurotoxins serotypes A and E cleave SNAP-25 at distinct COOH-terminal peptide bonds. FEBS Lett 335:99-103. CrossRef Medline

Schoepp DD, Jane DE, Monn JA (1999) Pharmacological agents acting at subtypes of metabotropic glutamate receptors. Neuropharmacology 38 : 1431-1476. CrossRef Medline

Schwartz EJ, Blackmer T, Gerachshenko T, Alford S (2007) Presynaptic G-protein-coupled receptors regulate synaptic cleft glutamate via transient vesicle fusion. J Neurosci 27:5857-5868. CrossRef Medline

Sladeczek F, Momiyama A, Takahashi T (1993) Presynaptic inhibitory action of a metabotropic glutamate receptor agonist on excitatory transmission in visual cortical neurons. Proc Biol Sci 253:297-303. CrossRef Medline

Slaughter MM, Miller RF (1981) 2-Amino-4-phosphonobutyric acid: a new pharmacological tool for retina research. Science 211:182-185. CrossRef Medline
Sokolov M, Strissel KJ, Leskov IB, Michaud NA, Govardovskii VI, Arshavsky VY (2004) Phosducin facilitates light-driven transducin translocation in rod photoreceptors: evidence from the phosducin knockout mouse. J Biol Chem 279:19149-19156. CrossRef Medline

Stella SL Jr, Thoreson WB (2000) Differential modulation of rod and cone calcium currents in tiger salamander retina by D2 dopamine receptors and cAMP. Eur J Neurosci 12:3537-3548. CrossRef Medline

Stella SL Jr, Bryson EJ, Thoreson WB (2002) A2 adenosine receptors inhibit calcium influx through L-type calcium channels in rod photoreceptors of the salamander retina. J Neurophysiol 87:351-360. CrossRef Medline

Stella SL Jr, Hu WD, Vila A, Brecha NC (2007) Adenosine inhibits voltagedependent $\mathrm{Ca}^{2+}$ influx in cone photoreceptor terminals of the tiger salamander retina. J Neurosci Res 85:1126-1137. CrossRef Medline

Stella SL Jr, Hu WD, Brecha NC (2009) Adenosine suppresses exocytosis from cone terminals of the salamander retina. Neuroreport 20:923-929. CrossRef Medline

Straiker A, Sullivan JM (2003) Cannabinoid receptor activation differentially modulates ion channels in photoreceptors of the tiger salamander. J Neurophysiol 89:2647-2654. CrossRef Medline

Straiker A, Stella N, Piomelli D, Mackie K, Karten HJ, Maguire G (1999) Cannabinoid CB1 receptors and ligands in vertebrate retina: localization and function of an endogenous signaling system. Proc Natl Acad Sci U S A 96:14565-14570. CrossRef Medline

Struik ML, Yazulla S, Kamermans M (2006) Cannabinoid agonist WIN $55212-2$ speeds up the cone response to light offset in goldfish retina. Vis Neurosci 23:285-293. CrossRef Medline

Szmajda BA, Devries SH (2011) Glutamate spillover between mammalian cone photoreceptors. J Neurosci 31:13431-13441. CrossRef Medline

Takahashi M, Freed R, Blackmer T, Alford S (2001) Calcium influxindependent depression of transmitter release by 5-HT at lamprey spinal cord synapses. J Physiol 532:323-336. CrossRef Medline

Takahashi T, Forsythe ID, Tsujimoto T, Barnes-Davies M, Onodera K (1996) Presynaptic calcium current modulation by a metabotropic glutamate receptor. Science 274:594-597. CrossRef Medline

Tedford HW, Zamponi GW (2006) Direct G protein modulation of Cav2 calcium channels. Pharmacol Rev 58:837-862. CrossRef Medline

Thompson PM, Rosenberger C, Holt S, Perrone-Bizzozero NI (1998) Measuring synaptosomal associated protein-25 $\mathrm{kDa}$ in human cerebral spinal fluid. J Psychiatr Res 32:297-300. CrossRef Medline

Thoreson WB, Rabl K, Townes-Anderson E, Heidelberger R (2004) A highly $\mathrm{Ca}^{2+}$-sensitive pool of vesicles contributes to linearity at the rod photoreceptor ribbon synapse. Neuron 42:595-605. CrossRef Medline

Ullrich B, Südhof TC (1994) Distribution of synaptic markers in the retina: implications for synaptic vesicle traffic in ribbon synapses. J Physiol Paris 88:249-257. CrossRef Medline

Van Hook MJ, Thoreson WB (2012) Rapid synaptic vesicle endocytosis in cone photoreceptors of salamander retina. J Neurosci 32:18112-18123. CrossRef Medline

Van Hook MJ, Thoreson WB (2013) Simultaneous whole-cell recordings from photoreceptors and second-order neurons in an amphibian retinal slice preparation. J Vis Exp e50007.

Van Hook MJ, Thoreson WB (2014) Endogenous calcium buffering at photoreceptor synaptic terminals in salamander retina. Synapse 68:518-528. CrossRef Medline

Van Hook MJ, Thoreson WB (2015) Weak endogenous $\mathrm{Ca}^{2+}$ buffering supports sustained synaptic transmission by distinct mechanisms in rod and cone photoreceptors in salamander retina. Physiol Rep 3:pii12567. CrossRef Medline

Van Hook MJ, Parmelee CM, Chen M, Cork KM, Curto C, Thoreson WB (2014) Calmodulin enhances ribbon replenishment and shapes filtering of synaptic transmission by cone photoreceptors. J Gen Physiol 144:357378. CrossRef Medline

von Gersdorff H, Schneggenburger R, Weis S, Neher E (1997) Presynaptic depression at a calyx synapse: the small contribution of metabotropic glutamate receptors. J Neurosci 17:8137-8146. Medline

Washbourne P, Pellizzari R, Baldini G, Wilson MC, Montecucco C (1997) Botulinum neurotoxin types $\mathrm{A}$ and $\mathrm{E}$ require the SNARE motif in SNAP-25 for proteolysis. FEBS Lett 418:1-5. CrossRef Medline

Wells CA, Zurawski Z, Betke KM, Yim YY, Hyde K, Rodriguez S, Alford S, Hamm HE (2012) G $\beta \gamma$ inhibits exocytosis via interaction with 
critical residues on soluble $\mathrm{N}$-ethylmaleimide-sensitive factor attachment protein-25. Mol Pharmacol 82:1136-1149. CrossRef Medline

Yamamoto S, Hisatomi O, Hasegawa A, Kobayashi Y, Tokunaga F (2007) Distribution and translocation of photoreceptor Gbetagammaphosducin system in medaka retina. Photochem Photobiol 83:35-39. CrossRef Medline

Yoon EJ, Gerachshenko T, Spiegelberg BD, Alford S, Hamm HE (2007) Gbetagamma interferes with $\mathrm{Ca}^{2+}$-dependent binding of synaptotagmin to the soluble $\mathrm{N}$-ethylmaleimide-sensitive factor attachment protein receptor (SNARE) complex. Mol Pharmacol 72:1210-1219. CrossRef Medline

Yoon EJ, Hamm HE, Currie KP (2008) G protein betagamma subunits modulate the number and nature of exocytotic fusion events in adrenal chromaffin cells independent of calcium entry. J Neurophysiol 100:29292939. CrossRef Medline
Zhang J, Wu SM (2005) Physiological properties of rod photoreceptor electrical coupling in the tiger salamander retina. J Physiol 564:849-862. CrossRef Medline

Zhang XL, Upreti C, Stanton PK (2011) G $\beta \gamma$ and the C terminus of SNAP-25 are necessary for long-term depression of transmitter release. PLoS One 6:e20500. CrossRef Medline

Zulliger R, Conley SM, Mwoyosvi ML, Stuck MW, Azadi S, Naash MI (2015) SNAREs interact with retinal degeneration slow and rod outer segment membrane protein-1 during conventional and unconventional outer segment targeting. PLoS One 10:e0138508. CrossRef Medline

Zurawski Z, Rodriguez S, Hyde K, Alford S, Hamm HE (2016) G $\beta \gamma$ binds to the extreme $\mathrm{C}$ terminus of SNAP2 5 to mediate the action of Gi/o-coupled G protein-coupled receptors. Mol Pharmacol 89:75-83. CrossRef Medline 